\title{
Source-receptor relationships for speciated atmospheric mercury at the remote Experimental Lakes Area, northwestern Ontario, Canada
}

\author{
I. Cheng ${ }^{1}$, L. Zhang ${ }^{2}$, P. Blanchard ${ }^{2}$, J. A. Graydon ${ }^{3}$, and V. L. St. Louis ${ }^{3}$ \\ ${ }^{1}$ Independent researcher, 5785 Yonge St, Toronto, Ontario, M2M 4J2, Canada \\ ${ }^{2}$ Air Quality Research Division, Science and Technology Branch, Environment Canada, 4905 Dufferin Street, Toronto, \\ Ontario, M3H 5T4, Canada \\ ${ }^{3}$ Department of Biological Sciences, University of Alberta, Edmonton, Alberta, T6G 2E9, Canada
}

Correspondence to: L. Zhang (leiming.zhang@ec.gc.ca)

Received: 7 September 2011 - Published in Atmos. Chem. Phys. Discuss.: 1 December 2011

Revised: 27 January 2012 - Accepted: 10 February 2012 - Published: 17 February 2012

\begin{abstract}
Source-receptor relationships for speciated atmospheric mercury measured at the Experimental Lakes Area (ELA), northwestern Ontario, Canada were investigated using various receptor-based approaches. The data used in this study include gaseous elemental mercury (GEM), mercury bound to fine airborne particles $(<2.5 \mu \mathrm{m})(\mathrm{PHg})$, reactive gaseous mercury (RGM), major inorganic ions, sulphur dioxide, nitric acid gas, ozone, and meteorological variables, all of which were measured between May 2005 and December 2006. The source origins identified were related to transport of industrial and combustion emissions (associated with elevated GEM), photochemical production of RGM (associated with elevated RGM), road-salt particles with absorption of gaseous $\mathrm{Hg}$ (associated with elevated PHg and RGM), crustal/soil emissions, and background pollution. Back trajectory modelling illustrated that a remote site, like ELA, is affected by distant $\mathrm{Hg}$ point sources in Canada and the United States. The sources identified from correlation analysis, principal components analysis and K-means cluster analysis were generally consistent. The discrepancies between the K-means and Hierarchical cluster analysis were the clusters related to transport of industrial/combustion emissions, photochemical production of RGM, and crustal/soil emissions. Although it was possible to assign the clusters to these source origins, the trajectory plots for the Hierarchical clusters were similar to some of the trajectories belonging to several K-means clusters. This likely occurred because the variables indicative of transport of industrial/combustion emissions were elevated in at least two or more of the clusters, which means this Hg source was well-represented in the data.
\end{abstract}

\section{Introduction}

Source-receptor relationship studies on atmospheric mercury $(\mathrm{Hg})$ advance our understanding of sources, transformation, transport, and fate of $\mathrm{Hg}$ in the environment, as well as provide scientific evidence for developing $\mathrm{Hg}$ control policies. Two major categories of methods exist in studying $\mathrm{Hg}$ source-receptor relationships: source-based and receptorbased methods. Source-based methods require source emission rates and profiles, meteorological forecasts, and knowledge of chemical reactions to predict pollutant concentrations at the receptor site (Bullock et al., 2000). Receptorbased methods mainly use ambient pollutant measurements to infer potential sources contributing to the receptor measurements and/or quantitatively apportion the contribution of major sources to receptor measurements (Hopke, 2003).

Many studies using source-based methods have been conducted for $\mathrm{Hg}$ during the past decade (e.g., Xu et al., 2000; Bullock and Brehme, 2002; Lin and Tao, 2003; Dastoor and Larocque, 2004; Christensen et al., 2004; Gbor et al., 2006; Ryaboshapko et al., 2007; Selin et al., 2007; Sillman et al., 2007; Bullock et al., 2008; Vijayaraghaven et al., 2008; Lin et al., 2010). The studies conducted sensitivity analyzes, model intercomparisons, and improved on the atmospheric $\mathrm{Hg}$ chemistry component of the model to better simulate RGM and PHg concentrations. Source-based atmospheric $\mathrm{Hg}$ models are advantageous because the models can predict three-dimensional fields of concentration and twodimensional fields of deposition (and thus regional-scale distribution), and can be used for conducting various sensitivity tests, e.g., predicting the effects of future emission scenarios, 
identifying contributions from different pollution sources and from individual chemical and physical processes. However, this approach requires extensive input data (e.g., reasonable emission inventory over the whole model domain) and consumes substantial computer resources. Currently, there are uncertainties in estimating $\mathrm{Hg}$ emissions from Asia, South America and Africa, natural sources, and previouslydeposited Hg (Gbor et al., 2006; Ryaboshapko et al., 2007; Dastoor et al., 2008; Lohman et al., 2008; Pirrone et al., 2010). Model uncertainties can also come from the meteorological model and $\mathrm{Hg}$ reaction mechanisms and kinetics data. Furthermore, only a few model simulations have been evaluated extensively with field measurements (Ryaboshapko et al., 2007; Bullock et al., 2008; Zhang et al., 2012).

Due to the complex atmospheric processes that need to be accounted for in model simulations, receptor-based methods may be used as an alternative or to complement source-based models (Hopke and Cohen, 2011). This approach also requires very limited computer resources. However, receptorbased methods are mainly concerned with ambient pollutant measurements at a particular site(s) of interest, and are not as capable as sources-based methods for many purposes discussed above. Another disadvantage of some receptor-based methods is that additional measurement data besides the pollutants studied might be needed in order to identify the potential emission sources (as shown in the present study).

Various techniques have been used in receptor-based methods. One technique uses multiple pollutants measurements to investigate source-receptor relationships, where a linear equation is used to represent a mass balance of the chemical species at the source and receptor site (see reviews in Hopke, 2003; Watson et al., 2008; Hopke and Cohen, 2011). For example, Pervez et al. (2009) used the Chemical Balance Model to apportion particulate $\mathrm{Hg}$ in dust samples; Keeler et al. (2006) applied the USEPA Positive Matrix Factorization (PMF) and UNMIX models to identify and apportion sources of Hg wet deposition; Cheng et al. (2009) also used PMF model to explore the sources of atmospheric $\mathrm{Hg}$ in an urban center. Another technique frequently used in receptor based speciated atmospheric $\mathrm{Hg}$ studies is to locate potential sources by tracking the movement of air parcels reaching the receptor site using back trajectory models, e.g., HYSPLIT (Hybrid Single Particle Lagrangian Integrated Trajectory) (Abbott et al., 2008; Li et al., 2008; Lyman and Gustin, 2008; Sprovieri et al., 2010a).

Combinations of the above two techniques with other techniques have also been used in receptor-based studies. For example, trajectory endpoints have been combined with source contributions from the PMF model or pollutant concentrations data to create Hybrid Receptor Models, such as Potential Source Contribution Function (PSCF), Simplified Quantitative Transport Bias Analysis (SQTBA), and Concentration Field Analysis (CFA). These methods have been employed to investigate source-receptor relationships for various atmospheric pollutants (Rua et al., 1998; Wang et al.,
2006; Du and Rodenburg, 2007) and validated through model intercomparisons (Lee and Ashbaugh, 2007; Scheifinger and Kaiser, 2007; Kabashnikov et al., 2011). Hybrid receptor models have also been used to identify source areas of atmospheric Hg (Han et al., 2005, 2007; Rutter et al., 2009; Xu and Akhtar, 2010).Conditional Probability Function uses local wind direction data instead of trajectory endpoints to determine wind sectors associated with elevated atmospheric Hg concentrations (Liu et al., 2007; Huang et al., 2010). The use of statistical analysis methods, such as Correlation Analysis, Principal Components Analysis and Cluster Analysis, have also been reported in other speciated atmospheric $\mathrm{Hg}$ studies (Liu et al., 2007; Brooks et al., 2009; Sigler et al., 2009; Huang et al., 2010). All the studies mentioned above typically employed one or more of the receptor-based techniques to create a more robust solution and interpretation of results.

Concentrations of speciated atmospheric $\mathrm{Hg}$, which includes gaseous elemental $\mathrm{Hg}$ (GEM), $\mathrm{Hg}$ bound to airborne particles (PHg), and reactive gaseous $\mathrm{Hg}(\mathrm{RGM})$, have been measured in polar, remote, rural, coastal, urban, and industrial areas (Sprovieri et al., 2010b). In the past, most speciated atmospheric $\mathrm{Hg}$ studies focused on analyzing trends in $\mathrm{Hg}$ and included brief discussions on the impacts of potential emission sources (Poissant et al., 2004; Gabriel et al., 2005; Hall et al., 2006; Manolopoulos et al., 2007; Song et al., 2009). However, identifying the contributions of different processes and sources to receptor measurements requires more sophisticated techniques discussed above. Longterm measurements of speciated atmospheric $\mathrm{Hg}$ are ideal for conducting such source-receptor relationship studies. To date, there are only a few studies in Canada investigating source-receptor relationships for speciated atmospheric $\mathrm{Hg}$, and mainly studied urban (Cheng et al., 2009; Song et al., 2009) and rural-agricultural/industrial settings (Poissant et al., 2004, 2005; Cobbett and Van Heyst, 2007; Baya and Van Heyst, 2010). Thus, it is currently unknown to what point sources or other factors were affecting atmospheric $\mathrm{Hg}$ concentrations in remote (non-polar) sites in Canada. One objective of the present study is to investigate the sourcereceptor relationships for speciated atmospheric $\mathrm{Hg}$ concentrations measured at a remote site in Canada. But it has also been realized that different receptor-based methods were not always consistent when applied to the same data set, with the discrepancies thought to be related to differences in their theoretical approaches (Viana et al., 2008). Thus, another objective of the present study is to conduct inter-comparisons of various receptor methods. 


\section{Methodology}

\subsection{Site description}

Measurements of speciated atmospheric $\mathrm{Hg}$ were conducted at the Experimental Lakes Area (ELA: latitude $49^{\circ} 39^{\prime} 50^{\prime \prime} \mathrm{N}$; longitude $93^{\circ} 43^{\prime} 16^{\prime \prime} \mathrm{W}$; elevation $369 \mathrm{~m}$ ), which is a remote Government of Canada field station in northwestern Ontario, Canada specializing in whole-ecosystem experimentation (Fig. 1). The site has a rugged Precambrian shield topography with hundreds of lakes ranging in size from 1 to $>200$ hectares surrounded by forested areas (ELA, 2010). The Tekran mercury speciation system is located at the ELA meteorological site (Atmospheric Environment Service designation: Rawson Lake Station), which is located approximately $0.5 \mathrm{~km}$ west of the ELA base station on lakes 239 and 240. The meteorological site is situated on a cleared granitic bedrock hill surrounded by a young jack pine/white birch forest regenerated following a fire in 1980. The surface below the sample inlet is bare bedrock. A Canadian Air and Precipitation Monitoring Network (CAPMoN) station is situated at the ELA site and has been monitoring ground-level $\mathrm{O}_{3}, \mathrm{SO}_{2}$ and $\mathrm{HNO}_{3}$ gases and total particulate $\mathrm{Ca}^{2+}, \mathrm{K}^{+}, \mathrm{Mg}^{2+}, \mathrm{Na}^{+}$, $\mathrm{Cl}^{-}, \mathrm{SO}_{4}^{2-}, \mathrm{NO}_{3}^{-}$, and $\mathrm{NH}_{4}^{+}$since the 1980s (ELA, 2010).

The ELA site is approximately $50 \mathrm{~km}$ east of Kenora, which is the closest city with a population of $\sim 15200$. The Trans-Canada highway is about $15 \mathrm{~km}$ north of the sampling site and a smaller highway (HWY71) is about $30 \mathrm{~km}$ west of the site. According to National Pollutant Release Inventory (Environment Canada, 2010), the nearest point source of $\mathrm{Hg}$ emissions is about $100 \mathrm{~km}$ southeast of the ELA site. There are also several non-Hg emitting industrial facilities (e.g., chemical pulp and paper mills, waferboard mills, wood product manufacturing) within $100 \mathrm{~km}$-radius of the ELA site that emit sulphur oxides, nitrogen oxides, volatile organic compounds, fine particulate matter, and/or ammonia to the atmosphere (Environment Canada, 2010).

\subsection{Speciated atmospheric mercury measurements}

Gaseous elemental mercury (GEM), mercury bound to particulate matter $<2.5 \mu \mathrm{m}(\mathrm{PHg})$, and reactive gaseous mercury (RGM) were measured using a Tekran mercury speciation system (Models 1130/1135/2537A). Speciated atmospheric $\mathrm{Hg}$ concentrations have been measured continuously since May 2005; the data used in this study covers the period between May 2005 and December 2006. The sample inlet was $1.31 \mathrm{~m}$ above ground level and sampled air at a flow rate of $101 \mathrm{~min}^{-1}$. Sampling flow rates for Tekran 2537A and 1130 were checked using Bios flow meters and were always within $5 \%$ and usually within $1 \%$ of the programmed values. GEM was measured every $5 \mathrm{~min}$ (reported as $1 \mathrm{~h}$ averages) except when PHg and RGM were analyzed and daily automated instrument calibrations were performed. The sampling interval for PHg and RGM was $3 \mathrm{~h}$ with a $1 \mathrm{~h}$ desorption/analysis cycle. Field blanks for GEM were recorded during daily automated calibrations and for PHg and RGM during desorption/analysis cycles. The detection limit for GEM was $0.1 \mathrm{ng} \mathrm{m}^{-3}$, whereas the detection limit for PHg and RGM were calculated as three times the standard deviation of the zero air values during desorption cycles over the course of the study $\left(0.33 \mathrm{pg} \mathrm{m}^{-3}\right)$. To ensure data accuracy, automated calibrations were performed every $28 \mathrm{~h}$ using an internal permeation source. Manual calibrations were also routinely carried out by injecting a known quantity of GEM into the 2537A Tekran approximately every 6 months of use. Automated and manual calibrations agreed within, on average $4.9 \pm 1.2 \%$ over the course of this study.

Although the accuracy of GEM measurements can be determined, calibration standards for RGM and $\mathrm{PHg}$ are not available because the chemical compositions of these species are not completely known. These species may be in the form of $\mathrm{Hg}(\mathrm{OH})_{2}, \mathrm{HgCl}_{2}, \mathrm{HgBr}_{2}$, or other halide compounds (Lindberg and Stratton, 1998); thus RGM and PHg are operationally defined. The current uncertainties of GEM and RGM concentrations are $10-20 \%$ and $30-40 \%$, respectively, based on measurements from collocated automated and manual sampling and analysis methods (Gustin and Jaffe, 2010). Furthermore there are uncertainties in $\mathrm{PHg}$ measurements due to presence of sampling artifacts when denuders are used (Lynam and Keeler, 2005; Malcolm and Keeler, 2007). This has led to renewed interest in developing field calibration methods, re-assessing the precision of the automated measurements with co-located Tekran speciation systems (Engle et al., 2008; Edgerton and Jansen, 2011), studying the effects of sampling artifacts and environmental interferences on atmospheric mercury measurements (Gustin and Jaffe, 2010; Lyman et al., 2010), and comparing automated methods to manual sampling and analysis techniques (Talbot et al., 2011). It is expected that the measurement uncertainties were smallest for GEM $(<20 \%)$ and largest for PHg (e.g., up to $70 \%$ ) based on previous studies discussed above.

\subsection{Supplementary data}

For our source-receptor relationship study, co-located and concurrent measurements of other pollutants and meteorological data, as well as locations of regional $\mathrm{Hg}$ point sources, were required. 24-h integrated trace gases and major ions concentrations in particulate matter were obtained from CAPMoN via NAtChem Database (2010), and hourly ground-level $\mathrm{O}_{3}$ concentrations were obtained from the NAPS network (2011). Hourly air temperature, relative humidity, wind speed and wind direction data were obtained from the Ontario Climate Centre (2010). Locations of regional $\mathrm{Hg}$ point sources (with annual $\mathrm{Hg}$ emissions $>5 \mathrm{~kg}$ ) were obtained from Canadian National Pollutant Release Inventory (Environment Canada, 2010) and US Toxics Release Inventory (USEPA, 2011). 


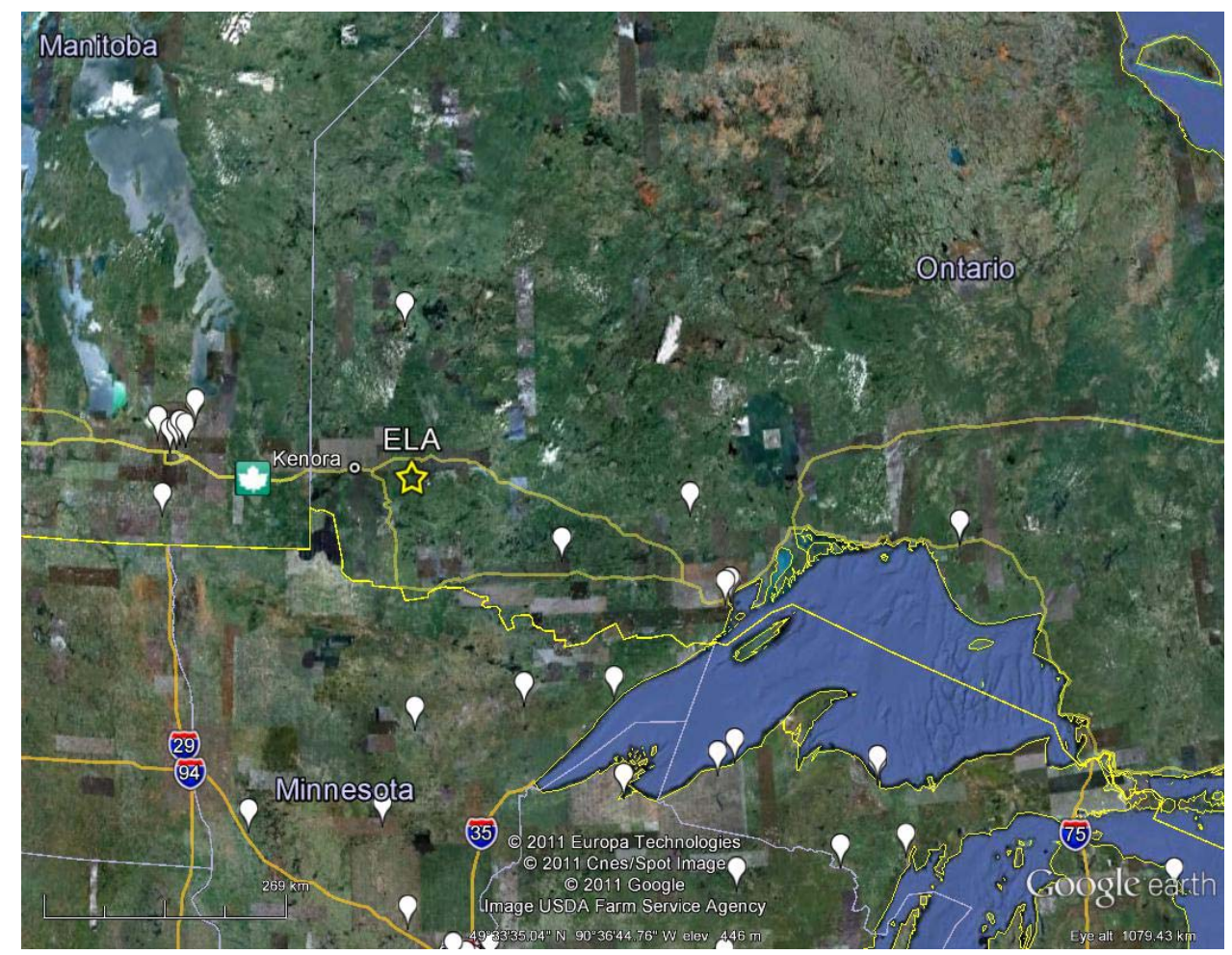

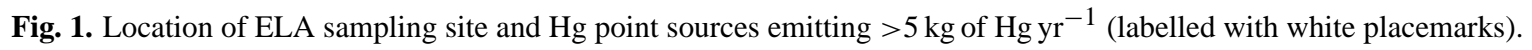

\subsection{Receptor-based methods}

\subsubsection{Analysis of trends and correlation analysis}

One-way analysis of variance was used to check for significant differences in the data between seasons, daytime and nighttime periods, and wind direction sectors. Spearman's rank correlation coefficient was used in correlation analysis of the daily averaged data for each season (i.e., winter $=\mathrm{DJF}$, spring $=$ MAM, summer $=$ JJA, fall $=$ SON). In Spearman's rank correlation, the daily averaged concentrations are placed in order (ranked) and correlations are performed on the ranks of the data (StatSoft, 2011).

\subsubsection{Principal components analysis}

Principal components analysis (PCA) is a data reduction method that groups a set of variables into a smaller set of factors (Pallant, 2005). PCA was chosen for this study because it can be used to analyse multiple pollutant and meteorological variables at once and has been used in several source-receptor studies of atmospheric Hg. Speciated atmospheric $\mathrm{Hg}$ data and hourly $\mathrm{O}_{3}$ concentrations and meteorological data were averaged daily to correspond with the 24$\mathrm{hr}$ integrated trace gases and major ions concentrations. The variables were normalized prior to running PCA.
The initial PCA run, which included the Kaiser-MeyerOlkin measure of sampling adequacy $(>0.6)$ and Bartlett's Test of sphericity $(p<0.05)$ tests, determined that PCA was a suitable method for the daily average data set. The number of factors to retain depends on the eigenvalue of each factor, scree plot, eigenvalues generated from Monte Carlo parallel analysis, and ability to characterize the factors (Pallant, 2005). Factors with eigenvalues greater than 1 and greater than those generated from parallel analysis were retained. Factors that are above a "bend" in the scree plot were also kept. In the second PCA run, the number of factors for the final solution was entered and the Varimax rotation method was selected. The output from PCA consists of a table with factor loadings, which are correlation coefficients between the variables and each factor. The variables with high factor loadings $(>0.5)$ were identified and used to interpret the potential sources of $\mathrm{Hg}$.

\subsubsection{Cluster analysis using K-means and hierarchical methods}

K-means and hierarchical cluster analysis are methods used to classify a large set of measurements or variables into clusters based on minimizing variation within clusters and maximizing variation between clusters (StatSoft, 2011). Cluster analysis was chosen for this study because the data clusters can be directly compared to the factors generated from PCA. 
This comparison is useful for evaluating PCA, since it is often applied on its own to air pollutants data. In both cluster analysis methods, the daily average pollutant concentrations (without meteorological variables) were used. In the $\mathrm{K}$-means method, the number of clusters needs to be specified. To compare with the factors obtained from PCA, the Kmeans method was run with 4, 5 and 6 clusters. The program begins with $k$ random clusters with initial centres; individual measurements are moved between these clusters by an iterative process in order to minimize variability within clusters and maximize variability between clusters. After the initial cluster centre is obtained, the program groups the next set of measurements in the iteration process based on the smallest euclidean distance from the cluster mean.

In hierarchical cluster analysis, variables were standardized to z-scores and pollutant measurements were clustered using a squared euclidean distance measure. Initially, each pollutant measurement is itself a cluster, which are then joined together into a new cluster based on the smallest squared euclidean distance measure. Afterwards the new clusters are grouped together using a linkage method, called Ward's method, which tries to minimize the sum of squares between the two clusters. This process continues until all clusters are grouped into one large cluster.

Clusters generated from K-means and Hierarchical methods were characterized into potential sources by identifying specific variables with elevated mean cluster centres (i.e., $>80$ th percentile concentration during the entire study period).

\subsubsection{HYSPLIT back trajectory modelling}

In addition to PCA and cluster analysis, back trajectories were generated to simulate the airflow from the ELA site. This can be used to identify and locate the specific types of anthropogenic sources that were interpreted from K-means and Hierarchical clusters. The HYSPLIT model (Draxler and Rolph, 2003; Rolph, 2003) of the NOAA Air Resources Laboratory was used to generate back trajectories for each day that was classified to a cluster. The EDAS (Eta Data Assimilation System) archived meteorological data, developed by the National Weather Service's National Centers for Environmental Prediction (NCEP), was selected as the meteorological input to the model. The meteorological data has been interpolated onto a $40 \mathrm{~km}$ grid that spans the United States and Canada. The vertical resolution covers 26 pressure surfaces from $1000 \mathrm{mbar}$ to $50 \mathrm{mbar}$. Three trajectories were generated each day and the total run time for each trajectory was $48 \mathrm{~h}$. The trajectory start height was $100 \mathrm{~m}$ above model ground level, which was determined from vertical sounding data and the actual elevation at the ELA site. Trajectories belonging to a cluster were plotted together on Google Earth as well as with regional $\mathrm{Hg}$ point sources with emissions $>5 \mathrm{~kg}$ of $\mathrm{Hg}$ per year as reported in Canadian National Pollutant Release Inventory and US Toxics Release Inventory.
Uncertainties in trajectories are typically $15-20 \%$ of the distance traveled. Stohl (1998) and Stohl et al. (2002) suggested the uncertainties may be due to errors in modeled wind fields, interpolating wind fields, truncating trajectory equations, turbulent mixing in the PBL and starting height of trajectories.

\section{Results and discussion}

\subsection{Speciated concentration patterns}

\subsubsection{Overall concentrations}

The mean and standard deviation for GEM, PHg and RGM concentrations between 17 May 2005 and 31 December 2006 (entire study period) were $1.57 \pm 0.22 \mathrm{ng} \mathrm{m}^{-3}$, $4.42 \pm 3.67 \mathrm{pg} \mathrm{m}^{-3}$ and $0.99 \pm 1.89 \mathrm{pg} \mathrm{m}^{-3}$, respectively (Table 1). As shown in Table 2, the average GEM concentrations at the ELA site were within the range of other remote sites and also slightly lower than rural locations with and without agricultural and industrial areas nearby. $\mathrm{PHg}$ concentrations at the ELA site were consistent with both the remote and rural sites, while the low RGM concentrations were consistent with only the remote sites. The finding that the measurements at the ELA site were in line with other remote sites not affected by anthropogenic $\mathrm{Hg}$ sources gives an idea about the precision of the Tekran speciated atmospheric $\mathrm{Hg}$ data. However, without calibration standards for $\mathrm{PHg}$ and RGM to verify the accuracy of the measurements, the following discussion of seasonal and diurnal trends is subject to uncertainties.

\subsubsection{Seasonal comparisons}

The seasonal average GEM concentration was highest during spring $2006\left(1.75 \mathrm{ng} \mathrm{m}^{-3}\right)$ compared to other seasons within the study period $(p<0.001)$ and also coincided with the highest average $\mathrm{O}_{3}$ concentration $(39 \mathrm{ppb}, p<0.001)$ and one of the lowest relative humidity levels $(67 \%, p<0.02)$. In other remote sites, the highest GEM concentrations were reported from winter to spring at Devil's Lake, Wisconsin (Manolopoulos et al., 2007), Adirondacks, New York (Choi et al., 2008), and two sites in New Hampshire (Sigler et al., 2009). Increased GEM concentrations from winter to spring at remote/rural sites in the Northern Hemisphere were attributed to increased emissions from coal and wood combustion during winter (Choi et al., 2008; Sigler et al., 2009). Enhanced emissions of GEM from soil and vegetation between mid-April to June due to warmer temperatures and dryer conditions have also been reported at other remote locations (Sigler et al., 2009), which can explain higher GEM concentrations in spring and summer.

Similar to GEM, RGM concentrations at ELA were highest during spring $2006\left(2.4 \mathrm{pg} \mathrm{m}^{-3}\right)$ compared to other seasons within the study period $(p<0.001)$ and also coincided 
Table 1. Descriptive statistics of data set for the ELA site for the period between 17 May 2005 and 31 December 2006.

\begin{tabular}{llllllll}
\hline Speciated atmospheric $\mathrm{Hg}$ & Mean & Standard deviation & Min. & Max. & $\%$ missing data & \# of data available & $\%$ of data $<$ DL \\
\hline $\mathrm{GEM}\left(\mathrm{ng} \mathrm{m}^{-3}\right)$ & 1.57 & 0.22 & 0.75 & 3.82 & 0.0 & 2361 & 0.0 \\
$\mathrm{PHg}\left(\mathrm{pg} \mathrm{m}^{-3}\right)$ & 4.42 & 3.67 & 0.00 & 42.33 & 5.2 & 2238 & 2.6 \\
$\mathrm{RGM}\left(\mathrm{pg} \mathrm{m}^{-3}\right)$ & 0.99 & 1.89 & 0.00 & 24.89 & 5.2 & 2239 & 51.4 \\
\hline Other pollutants & Mean & Standard deviation & Min. & Max. & $\%$ missing data & \# of valid data & $\%$ of data $<$ DL \\
\hline $\mathrm{SO}_{2}\left(\mu \mathrm{g} \mathrm{m}^{-3}\right)$ & 0.36 & 0.44 & 0.01 & 2.67 & 12.1 & 495 & 29.9 \\
$\mathrm{HNO}_{3}\left(\mu \mathrm{g} \mathrm{m}^{-3}\right)$ & 0.30 & 0.29 & 0.01 & 1.66 & 10.7 & 503 & 12.7 \\
$\mathrm{Ca}^{2+}\left(\mu \mathrm{g} \mathrm{m}^{-3}\right)$ & 0.17 & 0.28 & 0.01 & 3.20 & 5.7 & 531 & 38.0 \\
$\mathrm{Mg}^{2+}\left(\mu \mathrm{g} \mathrm{m}^{-3}\right)$ & 0.036 & 0.049 & 0.000 & 0.37 & 5.9 & 530 & 26.8 \\
$\mathrm{~K}^{+}\left(\mu \mathrm{g} \mathrm{m}^{-3}\right)$ & 0.034 & 0.040 & 0.000 & 0.31 & 5.7 & 531 & 31.8 \\
$\mathrm{Na}^{+}\left(\mu \mathrm{g} \mathrm{m}^{-3}\right)$ & 0.025 & 0.036 & 0.000 & 0.35 & 5.9 & 530 & 13.8 \\
$\mathrm{Cl}^{-}\left(\mu \mathrm{g} \mathrm{m}^{-3}\right)$ & 0.017 & 0.027 & 0.000 & 0.35 & 5.9 & 530 & 70.8 \\
$\mathrm{NH}_{4}^{+}\left(\mu \mathrm{g} \mathrm{m}^{-3}\right)$ & 0.33 & 0.44 & 0.00 & 3.22 & 5.7 & 531 & 6.0 \\
$\mathrm{NO}_{3}^{-}\left(\mu \mathrm{g} \mathrm{m}^{-3}\right)$ & 0.32 & 0.61 & 0.02 & 6.58 & 5.7 & 531 & 22.8 \\
$\mathrm{SO}_{4}^{2-}\left(\mu \mathrm{g} \mathrm{m}^{-3}\right)$ & 0.91 & 1.16 & 0.01 & 9.17 & 5.7 & 531 & 6.2 \\
$\mathrm{O}_{3}(\mathrm{ppb})$ & 30.97 & 10.17 & 5.00 & 68.33 & 0.2 & 2357 & \\
\hline
\end{tabular}

Table 2. Speciated atmospheric mercury concentrations at selected remote and rural sites.

\begin{tabular}{|c|c|c|c|c|c|c|}
\hline Location & Time of sampling & Site description & GEM/TGM ng m ${ }^{-3}$ & $\mathrm{PHg} \mathrm{pg} \mathrm{m^{-3 }}$ & RGM pg m ${ }^{-3}$ & Reference \\
\hline Experimental Lakes Area, Ontario, Canada & May 2005-December 2006 & Remote & $1.56 \pm 0.22$ & $4.42 \pm 3.67$ & $0.99 \pm 1.89$ & This Study \\
\hline Devil's Lake, Wisconsin, & April 2003-2004 & Remote & $1.6 \pm 0.3$ & $8.6 \pm 8.3$ & $3.8 \pm 8.9$ & Manolopoulos et al. (2007) \\
\hline Adirondacks, New York & June 2006-May 2007 & Remote & $1.4 \pm 0.4$ & $3.2 \pm 3.7$ & $1.8 \pm 2.2$ & Choi et al. (2008) \\
\hline Yellowstone National Park, USA & 3-12 September 2003 & Remote & $<1$ to 2.5 & $<\mathrm{DL}$ to 30 & $<0.88$ to 5 & Hall et al. (2006) \\
\hline Thompson Farm, New Hampshire & 2007 & Remote & 1.4 & $\mathrm{n} / \mathrm{a}$ & 3.6 & Sigler et al. (2009) \\
\hline Pac Monadnock, New Hampshire & 2007 & Remote & 1.4 & $\mathrm{n} / \mathrm{a}$ & 1.2 & Sigler et al. (2009) \\
\hline Salmon Falls Creek Reservoir, Idaho & $\begin{array}{l}\text { July and November } 2005 \text {; } \\
\text { February and May } 2006\end{array}$ & Remote & 1.32 to $1.91^{*}$ & $\mathrm{n} / \mathrm{a}$ & 2.3 to $8.2^{*}$ & Abbott et al. (2008) \\
\hline Dexter, Michigan & 2004 & Rural & $1.59 \pm 0.59$ & $6.10 \pm 5.51$ & $3.80 \pm 6.62$ & Liu et al. (2010) \\
\hline Great Smoky Mountains Nat'l Park, USA & May 2004 to August 2004 & Rural & 1.65 & 7 & 5 & Valente et al. (2007) \\
\hline Elora, Ontario & November 2006 to August 2007 & Rural-agriculture & $1.2 \pm 0.51$ & $16.4 \pm 9.54$ & $15.1 \pm 10.02$ & Baya and Van Heyst (2010) \\
\hline Maryhill, Ontario & October to November 2004 & Rural-agriculture & $1.8 \pm 0.2$ & $3.0 \pm 6.2$ & $2.3 \pm 3.0$ & Cobbett and Van Heyst (2007) \\
\hline St. Anicet, Quebec & 2003 & Rural-agriculture & $1.65 \pm 0.42$ & $26 \pm 54$ & $3 \pm 11$ & Poissant et al. (2005) \\
\hline Calero, San Francisco Bay Area & 2005 and 2008 & Rural-industrial & 1.85 to $2.37^{*}$ & 3.68 to $7.99^{*}$ & 4.58 to $14.5^{*}$ & Rothenberg et al. (2010) \\
\hline Cove Mountain, Tennessee & August to September 2002 & Rural-industrial & 2 to 5 & 3 to 75 & 3 to 60 & Gabriel et al. (2005) \\
\hline Athens, Ohio & July 2004 to July 2005 & Rural-industrial & $1.62 \pm 0.24$ & $5.29 \pm 6.04$ & $12.45 \pm 24.53$ & Yatavelli et al. (2006) \\
\hline
\end{tabular}

* This is the range of the mean concentrations over the study periods, instead of from min. to max.

with the highest average $\mathrm{O}_{3}$ concentration $(39 \mathrm{ppb}, p<$ $0.001)$ and one of the lowest relative humidity levels $(67 \%$, $p<0.02$ ). RGM concentrations were also highest during the spring at Devil's Lake and in New Hampshire and during winter and summer at the Adirondacks. Maximum summer concentrations of GEM and RGM have also been observed at the remote site of Salmon Falls Creek, Idaho (Abbott et al., 2008).

At the ELA site, PHg concentrations were higher during winter, spring and summer $2006\left(5.10-5.23 \mathrm{pg} \mathrm{m}^{-3}\right)$ compared with other seasons $(p<0.06)$. Winter 2006 also corresponded to lowest average temperature $\left(-9.6^{\circ} \mathrm{C}, p<0.001\right)$ and highest mean concentrations of $\mathrm{SO}_{2}\left(0.69 \mu \mathrm{g} \mathrm{m}^{-3}, p<\right.$ $0.001)$ and $\mathrm{Na}^{+}\left(0.06 \mu \mathrm{g} \mathrm{m}^{-3}, p<0.001\right)$. Summer 2006 was the warmest season during the entire study with an av- erage temperature of $19^{\circ} \mathrm{C}(p<0.001)$, and also similar to spring 2006, one of the lowest relative humidity levels (67\%, $p<0.02$ ). The higher PHg concentrations in the winter at the ELA site were consistent with other remote and rural studies, which suggested that this observation was related to increased emissions from coal and wood combustion in winter, condensation of gases on atmospheric particles at lower temperatures, and re-suspension of particles during windy conditions (Choi et al., 2008; Huang et al., 2010, 2011). In urban settings, the summer maximum in $\mathrm{PHg}$ has been attributed to higher $\mathrm{PM}_{2.5}$ concentrations in the summer, which provides more surface area for $\mathrm{Hg}$ absorption (Huang et al., 2010). Unfortunately, $\mathrm{PM}_{2.5}$ concentrations were not measured at the ELA site to verify this point. 
At rural sites near agricultural areas, maximum $\mathrm{PHg}$ concentrations occurred in spring or fall corresponding to ploughing or harvesting activities that can increase soil erosion (Poissant et al., 2005; Cobbett and Van Heyst, 2007). Although the lowest atmospheric $\mathrm{Hg}$ concentrations were observed during fall 2005 (1.37 $\mathrm{ng} \mathrm{m}^{-3}$ for GEM, $2.4 \mathrm{pg} \mathrm{m}^{-3}$ for PHg, $0.08 \mathrm{pg} \mathrm{m}^{-3}$ for RGM), only GEM concentrations were significantly different from the other seasons $(p<$ $0.001)$. Fall 2005 also corresponded to the lowest $\mathrm{O}_{3}$ concentrations $(24 \mathrm{ppb}, p<0.001)$.

\subsubsection{Diurnal variability}

The relative standard deviation (daily standard deviation/daily mean expressed as a \%) in the concentrations for each day on average is $\pm 3 \%$ from the mean for GEM, $\pm 12 \%$ from the mean for PHg and $\pm 52 \%$ from the mean for RGM for the entire study period. One-way ANOVA (Analysis of Variance) with post-hoc tests was used to compare the mean GEM and RGM concentrations between each of the hours and assess whether each hour was statistically different from other hours. Statistical differences were observed for GEM and RGM between 07:00-09:00 and 13:00-19:00 LT $(p<0.05)$, with higher concentrations observed from 13:00-19:00. In other remote and rural studies, RGM concentrations were typically higher during the day than at night (Poissant et al., 2005; Hall et al., 2006; Manolopoulos et al., 2007; Abbott et al., 2008; Sigler et al., 2009; Liu et al., 2010). Based on statistical comparison of the other variables between the two time periods, higher temperatures, wind speeds and $\mathrm{O}_{3}$ concentrations and lower relative humidity levels were also observed at the ELA site from 13:00-19:00 $(p<0.05)$.

Elevated RGM and $\mathrm{O}_{3}$ concentrations and low relative humidity may be a signature of free troposphere air as discussed in Swartzendruber et al. (2006) and Weiss-Penzias et al. (2009). At the Mt. Bachelor Observatory site in Oregon, US, maximum diel RGM concentrations $\left(>50 \mathrm{pg} \mathrm{m}^{-3}\right)$ typically occurred at night along with elevated ozone (up to $60 \mathrm{ppb}$ ) and low water vapor $\left(2.2 \mathrm{~g} \mathrm{~kg}^{-1}\right)$ (Swartzendruber et al., 2006). Maximum diel RGM concentrations for the three sites in Nevada, US ranged from $55-140 \mathrm{pg} \mathrm{m}^{-3}$ during daytime along with higher ozone (ranging from 50-60 ppb) and low relative humidity ranging from $12-55 \%$ (Weiss-Penzias et al., 2009). Compared to the ELA site, the maximum diel $\mathrm{RGM}$ and $\mathrm{O}_{3}$ concentrations were on average $2.6 \mathrm{pg} \mathrm{m}^{-3}$ and $37 \mathrm{ppb}$, and relative humidity ranged from $56-83 \%$. The large differences observed may be due to the different location, altitude and atmospheric circulation patterns affecting the sites. The downward transport of free troposphere air is believed to be driven by katabatic winds from mountains (Swartzendruber et al., 2006), subtropical high pressure system affecting higher altitude western US sites (Fiore et al., 2003; Weiss-Penzias et al., 2009) and tropical deserts (Arkian et al., 2010).
Surface measurements of beryllium-7 $\left({ }^{7} \mathrm{Be}\right)$, a cosmogenic radioactive nuclide found mainly in the stratosphere, and RGM may be useful for examining whether the free troposphere is a potential source of RGM (Amos et al., 2012). But RGM concentrations can still be affected by anthropogenic sources and other processes, such as wet deposition and photochemical production by atmospheric oxidants. Similarly, many factors, such as season, location, atmospheric circulation, and wet scavenging, can also affect surface ${ }^{7}$ Be activity (Yoshimori, 2007; Arkian et al., 2010).

By season, the largest diurnal variability for GEM occurred in spring and fall 2005, in which the latter season coincided with the largest diurnal variations in temperature, relative humidity and $\mathrm{O}_{3}$ concentrations compared with other seasons (see Fig. 2a). In fall and winter 2006, the smallest diurnal variations in GEM, meteorological conditions, and $\mathrm{O}_{3}$ were found. For PHg and RGM, the diurnal changes were largest in spring 2006, even though the diurnal variations in meteorological conditions and $\mathrm{O}_{3}$ concentrations were not the largest or smallest compared with other seasons (see Fig. $2 \mathrm{~b}$ and c). The smallest diurnal variability for PHg occurred in winter 2006 similar to GEM, but for RGM, this occurred in fall 2005 when the largest diurnal variation in temperature, relative humidity and $\mathrm{O}_{3}$ concentrations were observed. The data suggests that the diurnal variation in GEM was more strongly influenced by changes in meteorological conditions than diurnal variations in $\mathrm{PHg}$ and RGM. Other studies conducted in remote/rural sites suggested the diurnal variation of GEM can also be due to a combination of changes in mixing height, meteorology, surface emissions and/or photo-reduction of RGM (Gabriel et al., 2005; Yatavelli et al., 2006; Manolopoulos et al., 2007; Choi et al., 2008, 2009; Sigler et al., 2009). Diurnal trends for PHg and RGM could be due to variations in source emissions and wind patterns, and photochemical processes (Manolopoulos et al., 2007; Abbott et al., 2008; Choi et al., 2008; Sigler et al., 2009).

\subsubsection{Wind direction variability}

The prevailing wind (excluding calm wind speeds, $<4 \mathrm{~km} \mathrm{~h}^{-1}$ ) at the ELA site during the entire study period was from the southwest and south $(18 \%$ and $17 \%$ of the data, respectively). However, the highest average GEM and RGM concentrations were observed when winds were from the southeast, which made up only $11 \%$ of the wind data. These average concentrations were found to be statistically higher than those that occurred when winds were out of the west and northwest $(p<0.02$ for GEM and $p<0.001$ for RGM). Average PHg concentration was highest when winds originated from the southwest, and statistically higher than those that occurred when winds were from west, northwest, and northeast $(p<0.007)$. The average concentrations of the majority of the trace gases and major ions were highest from the south, which was fairly consistent with the speciated 

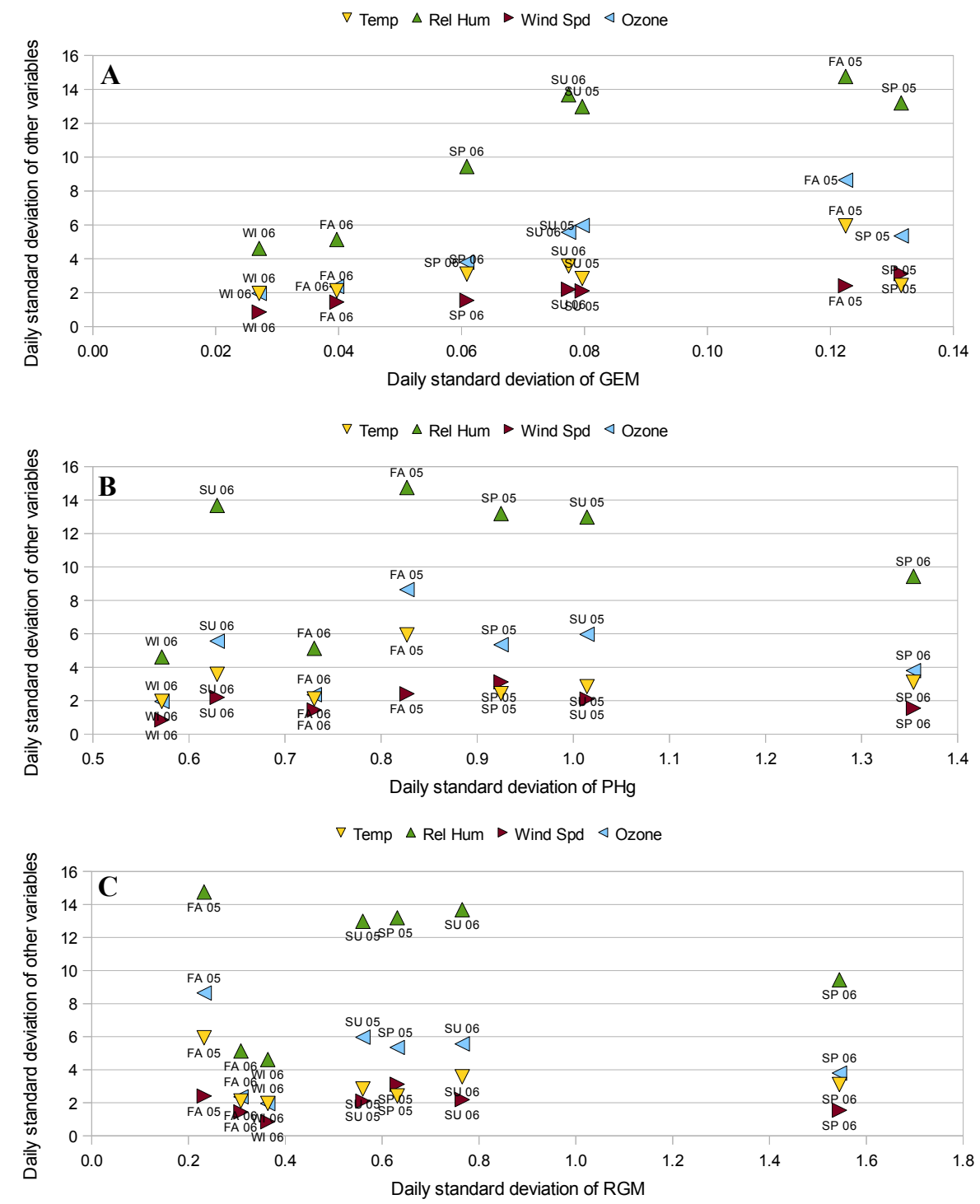

Fig. 2. Effect of diurnal variability of temperature, relative humidity, wind speed, and ground-level $\mathrm{O}_{3}$ on the diurnal variability of (A) GEM, (B) PHg, and (C) RGM for each season (WI = winter, SP = spring, SU = summer, FA = fall; $05=2005$ year, $06=2006$ year). The daily standard deviation is used as a measure of diurnal variability.

atmospheric $\mathrm{Hg}$ results. The mean $\mathrm{SO}_{2}$ concentrations from the south were significantly different than those from northeast $(p<0.02)$. For $\mathrm{Ca}^{2+}, \mathrm{K}^{+}$and $\mathrm{Mg}^{2+}$, the average concentrations observed when winds were out of the south were significantly different than those when winds from northwest $(p<0.04)$. The average concentrations of $\mathrm{NH}_{4}^{+}$, $\mathrm{NO}_{3}^{-}, \mathrm{SO}_{4}^{2-}$, and $\mathrm{HNO}_{3}$ observed when winds were from the south were statistically different than the winds observed from southwest, west, and northwest $(p<0.03)$. Average $\mathrm{HNO}_{3}$ concentrations from the south were also significantly larger than those from all other wind directions $(p<0.02)$. For $\mathrm{Na}^{+}$, only the mean concentration from the east was significantly higher than from the southwest $(p<0.03)$. The average $\mathrm{Cl}^{-}$concentrations associated with a particular wind direction were not statistically different than those from other wind directions.

\subsection{Correlation analysis}

The Spearman rank correlation coefficients between $\mathrm{PHg}$ and other $\mathrm{Hg}$ species and pollutants for each season are shown in Table 3a, while the correlation coefficients for selected pollutants indicative of various source origins for each season are shown in Table $3 b$. In Table 3a, correlation analyses are conducted with fine particulate mercury because the ions are associated with particulate matter. Using PHg would be more appropriate for identifying $\mathrm{Hg}$ from crustal/soil dust and seasalt or road-salt, which are in the particulate phase as well. 
Table 3a. Spearman rank correlation coefficients between $\mathrm{PHg}$ and other pollutants.

\begin{tabular}{lrrrrrr}
\hline & \multicolumn{7}{c}{ PHg } \\
\hline & Summer 2005 & Fall 2005 & Winter 2006 & Spring 2006 & Summer 2006 & Fall 2006 \\
\hline $\mathrm{GEM}$ & $\mathbf{0 . 3 9}$ & $\mathbf{0 . 3 9}$ & -0.19 & 0.18 & $\mathbf{0 . 5 3}$ & $\mathbf{0 . 5 0}$ \\
$\mathrm{RGM}$ & $\mathbf{0 . 5 7}$ & $\mathbf{0 . 3 9}$ & $\mathbf{0 . 7 0}$ & $\mathbf{0 . 6 2}$ & $\mathbf{0 . 4 7}$ & $\mathbf{0 . 6 7}$ \\
$\mathrm{SO}_{2}$ & $\mathbf{0 . 4 3}$ & $\mathbf{0 . 4 9}$ & -0.01 & $\mathbf{0 . 5 2}$ & $\mathbf{0 . 3 0}$ & $\mathbf{0 . 3 8}$ \\
$\mathrm{HNO}_{3}$ & $\mathbf{0 . 3 6}$ & $\mathbf{0 . 7 8}$ & -0.21 & $\mathbf{0 . 3 4}$ & $\mathbf{0 . 4 9}$ & $\mathbf{0 . 6 8}$ \\
$\mathrm{Ca}^{2+}$ & $\mathbf{0 . 5 4}$ & $\mathbf{0 . 6 2}$ & 0.20 & $\mathbf{0 . 3 9}$ & $\mathbf{0 . 5 0}$ & $\mathbf{0 . 6 6}$ \\
$\mathrm{Mg}^{2+}$ & $\mathbf{0 . 4 8}$ & $\mathbf{0 . 6 2}$ & $\mathbf{0 . 5 8}$ & $\mathbf{0 . 5 6}$ & $\mathbf{0 . 5 0}$ & $\mathbf{0 . 6 1}$ \\
$\mathrm{K}^{+}$ & $\mathbf{0 . 4 0}$ & $\mathbf{0 . 6 8}$ & 0.05 & $\mathbf{0 . 2 1}$ & $\mathbf{0 . 5 8}$ & $\mathbf{0 . 7 3}$ \\
$\mathrm{Na}^{+}$ & $\mathbf{0 . 3 5}$ & $\mathbf{0 . 4}$ & $\mathbf{0 . 7 3}$ & $\mathbf{0 . 4 1}$ & 0.09 & $\mathbf{0 . 2 1}$ \\
$\mathrm{Cl}^{-}$ & 0.24 & 0.09 & $\mathbf{0 . 5 2}$ & 0.02 & $\mathbf{0 . 4 1}$ & $\mathbf{0 . 3 5}$ \\
$\mathrm{NH}_{4}^{+}$ & $\mathbf{0 . 6 2}$ & $\mathbf{0 . 6 1}$ & -0.21 & 0.18 & $\mathbf{0 . 4 3}$ & $\mathbf{0 . 5 0}$ \\
$\mathrm{NO}_{3}^{-}$ & $\mathbf{0 . 6 3}$ & $\mathbf{0 . 6 9}$ & $\mathbf{0 . 3 0}$ & $\mathbf{0 . 3 0}$ & $\mathbf{0 . 3 4}$ & $\mathbf{0 . 6 4}$ \\
$\mathrm{SO}_{4}^{2-}$ & $\mathbf{0 . 6 2}$ & $\mathbf{0 . 6 2}$ & $-\mathbf{0 . 4 0}$ & $\mathbf{0 . 2 8}$ & $\mathbf{0 . 3 8}$ & $\mathbf{0 . 4 0}$ \\
$\mathrm{O}_{3}$ & $\mathbf{0 . 6 8}$ & $\mathbf{0 . 3 7}$ & $\mathbf{0 . 6 6}$ & $\mathbf{0 . 6 2}$ & $\mathbf{0 . 2 7}$ & 0.16 \\
\hline
\end{tabular}

Correlation coefficients shown in bold were statistically significant $(p<0.05)$.

Winter months: December, January, February; Spring months: March, April, May; Summer months: June, July, August; Fall months: September, October, November.

For industrial/combustion sources and photochemical/gasphase oxidation, correlations between gaseous $\mathrm{Hg}$ species, i.e., GEM and RGM, were examined (Table 3b).

Strong correlations between variables indicative of crustal/soil sources and marine sources (i.e., $\mathrm{Ca}^{2+}, \mathrm{K}^{+}$, $\mathrm{SO}_{4}^{2-}, \mathrm{Na}^{+}, \mathrm{Cl}^{-}, \mathrm{Mg}^{2+}$ as discussed by Prendes et al. (1999), Mouli et al. (2005), and Viana et al., 2008) were found in every season (see Table 3b), except for spring 2005, which was excluded from the analysis due to the small number of speciated $\mathrm{Hg}$ data points. As shown in Table 3a, most of these variables individually were correlated with $\mathrm{PHg}$ in every season (except for winter 2006), suggesting that the source of atmospheric $\mathrm{Hg}$ may be from re-suspended dust (from crustal/soil, road dust, point source dust emissions) containing previously-deposited $\mathrm{Hg}$ or adsorption of gaseous $\mathrm{Hg}$ on sea-salt aerosols. Particulate $\mathrm{Hg}$ can be formed by absorption or condensation of GEM or RGM onto these particles (Schroeder and Munthe, 1998; Lu et al., 2001). Although crustal/soil and marine sources are often difficult to differentiate because they have similar compositions, Prendes et al. (1999) suggested that a lack of correlation between $\mathrm{K}$ and $\mathrm{Ca}$ and $\mathrm{Na}$ and $\mathrm{Cl}$ can be used to attribute particulate matter to construction and earthworks (i.e., crustal/soil as opposed to marine sources). In our study, a lack of correlation between these variables was observed in fall 2005 and spring 2006 (see Table 3b). For these seasons, the source of atmospheric $\mathrm{Hg}$ would be related to crustal/soil dust containing previously-deposited $\mathrm{Hg}$.

In winter 2006, $\mathrm{PHg}$ was strongly correlated with $\mathrm{Na}^{+}$, $\mathrm{Cl}^{-}$and $\mathrm{Mg}^{2+}$ (marine components) but not with $\mathrm{Ca}^{2+}$ and $\mathrm{K}^{+}$(see Table 3a). While significant scavenging of RGM by sea-salt aerosols have been reported in coastal areas (Selin et al., 2007; Malcolm et al., 2009), the transport of $\mathrm{Hg}$ bounded to sea-salt aerosols would not be the likely source of atmospheric $\mathrm{Hg}$ to a mid-continental site such as the ELA. Furthermore, $\mathrm{Hg}$ associated with sea-salt aerosols are typically larger than 2 to $2.5 \mu \mathrm{m}$, which means most of the sea-salt aerosols would be excluded by the $2.5 \mu \mathrm{m}$ impactor and not efficiently pass through the annular denuder of the Tekran speciation unit (Obrist et al., 2011; Talbot et al., 2011). Thus, the most probable source of $\mathrm{PHg}$ during winter is the transport of road dust that contained components of road-salt with absorption or condensation of gaseous Hg. The above suggestion was supported by size-distribution data of $\mathrm{Na}^{+}, \mathrm{Cl}^{-}$ and $\mathrm{Mg}^{2+}$ collected at another rural site in Ontario (Algoma) and discussions on sea salt and road salt effects as presented in Zhang et al. (2008).

Variables related to agricultural sources (i.e., $\mathrm{NH}_{4}^{+}$and $\mathrm{NO}_{3}^{-}$as discussed in Mouli et al., 2005) were correlated with each other and with PHg in the summer and fall seasons (Table $3 a$ and $b$ ), which could mean the source of $\mathrm{Hg}$ is from the erosion of agricultural soil containing previously-deposited $\mathrm{Hg}$. $\mathrm{NH}_{4}^{+}$is formed from the reaction of nitric acid and sulphuric acid with ammonia, which might have originated from the use of fertilizers for farming and chemical pulp and paper mills near the ELA site. Elevated PHg concentrations have been observed at rural sites near agricultural areas in Ontario, Canada, and typically occurred during the spring and fall seasons (Poissant et al., 2005; Cobbett and Van Heyst, 2007; Baya and Van Heyst, 2010). In one of the studies, elevated $\mathrm{PHg}$ concentrations were related to the agricultural practice of applying biosolids (from sewage wastes) containing low concentrations of $\mathrm{Hg}$ (Cobbett and Van Heyst, 2007). 
Table 3b. Spearman rank correlation coefficients for selected pollutants indicative of source origins.

\begin{tabular}{|c|c|c|c|c|c|c|}
\hline & Summer 2005 & Fall 2005 & Winter 2006 & Spring 2006 & Summer 2006 & Fall 2006 \\
\hline \multicolumn{7}{|c|}{ Re-suspended dust (from crustal/soil/road/point sources) or sea-salt origin } \\
\hline $\mathrm{Ca}^{2+}$ and $\mathrm{K}^{+}$ & 0.27 & 0.69 & 0.40 & 0.66 & 0.54 & $\mathbf{0 . 7 0}$ \\
\hline $\mathrm{SO}_{4}^{2-}$ and $\mathrm{Ca}^{2+}$ & 0.64 & 0.42 & -0.18 & 0.60 & 0.49 & 0.45 \\
\hline $\mathrm{Na}^{+}$and $\mathrm{Cl}^{-}$ & 0.40 & 0.62 & 0.62 & 0.38 & 0.26 & 0.41 \\
\hline $\mathrm{K}^{+}$and $\mathrm{Cl}^{-}$ & 0.45 & 0.02 & 0.18 & 0.17 & 0.56 & 0.24 \\
\hline $\mathrm{Na}^{+}$and $\mathrm{Ca}^{2+}$ & 0.32 & 0.18 & 0.38 & 0.18 & 0.32 & 0.26 \\
\hline $\mathrm{Ca}^{2+}$ and $\mathrm{Cl}^{-}$ & 0.27 & 0.08 & 0.43 & 0.06 & 0.23 & 0.29 \\
\hline $\mathrm{Na}^{+}$and $\mathrm{K}^{+}$ & 0.47 & 0.06 & 0.04 & -0.02 & 0.37 & 0.21 \\
\hline $\mathrm{Mg}^{2+}$ and $\mathrm{Ca}^{2+}$ & 0.96 & 0.91 & 0.66 & 0.87 & 0.97 & 0.93 \\
\hline $\mathrm{Mg}^{2+}$ and $\mathrm{Cl}^{-}$ & 0.17 & 0.21 & 0.70 & 0.18 & 0.21 & 0.30 \\
\hline $\mathrm{Mg}^{2+}$ and $\mathrm{Na}^{+}$ & 0.30 & 0.31 & 0.80 & 0.38 & 0.27 & 0.35 \\
\hline \multicolumn{7}{|c|}{ Agricultural activities origin } \\
\hline $\mathrm{NH}_{4}^{+}$and $\mathrm{NO}_{3}^{-}$ & 0.76 & 0.72 & 0.48 & 0.72 & 0.55 & 0.73 \\
\hline \multicolumn{7}{|c|}{ Industrial transport origin } \\
\hline $\mathrm{SO}_{2}$ and $\mathrm{SO}_{4}^{2-}$ & 0.63 & 0.43 & 0.11 & 0.61 & 0.44 & 0.47 \\
\hline $\mathrm{SO}_{4}^{2-}$ and $\mathrm{NH}_{4}^{+}$ & 0.99 & 0.95 & 0.68 & 0.95 & 0.96 & 0.60 \\
\hline $\mathrm{SO}_{2}$ and $\mathrm{NO}_{3}^{-}$ & 0.57 & 0.56 & 0.16 & 0.53 & 0.46 & 0.36 \\
\hline $\mathrm{NO}_{3}^{-}$and $\mathrm{SO}_{4}^{2-}$ & 0.78 & 0.68 & -0.04 & 0.67 & 0.67 & 0.60 \\
\hline $\mathrm{RGM}$ and $\mathrm{SO}_{2}$ & 0.73 & 0.45 & 0.09 & 0.52 & 0.39 & 0.48 \\
\hline $\mathrm{RGM}$ and $\mathrm{Cl}^{-}$ & 0.10 & -0.12 & 0.28 & -0.09 & 0.31 & 0.33 \\
\hline \multicolumn{7}{|c|}{ Photochemical/gas phase oxidation origin } \\
\hline $\mathrm{GEM}$ and $\mathrm{O}_{3}$ & 0.56 & 0.62 & 0.09 & 0.31 & 0.36 & 0.19 \\
\hline $\mathrm{RGM}$ and $\mathrm{O}_{3}$ & 0.68 & 0.34 & 0.65 & 0.78 & 0.31 & 0.29 \\
\hline GEM and RGM & 0.57 & 0.06 & 0.05 & 0.08 & 0.30 & 0.63 \\
\hline
\end{tabular}

Correlation coefficients shown in bold were statistically significant $(p<0.05)$.

Winter months: December, January, February; Spring months: March, April, May; Summer months: June, July, August; Fall months: September, October, November.

There is also some evidence of atmospheric $\mathrm{Hg}$ concentrations being affected by the transport of industrial emissions due to moderate correlations between $\mathrm{SO}_{2}$, secondary pollutants $\left(\mathrm{NH}_{4}^{+}, \mathrm{NO}_{3}^{-}, \mathrm{SO}_{4}^{2-}\right.$ as discussed in Lee and Hopke, 2006; Viana et al., 2008; and Masiol et al., 2010) and PHg. The emissions may be related to combustion sources, such as waste incineration and coal combustion, because RGM was correlated with $\mathrm{SO}_{2}$ in the spring, summer and fall seasons. RGM and $\mathrm{Cl}^{-}$were also correlated in the summer and fall of 2006 (see Table 3b). According to Carpi (1997), $\mathrm{Hg}$ from waste incineration is emitted mostly in the divalent form (75-85\%), while divalent $\mathrm{Hg}$ (mostly $\mathrm{HgCl}_{2}$ ) makes up $50-80 \%$ of $\mathrm{Hg}$ emitted from coal combustion. The relatively shorter atmospheric residence time of RGM compared to GEM means the deposition of RGM is close to its source of emission (Schroeder and Munthe, 1998).

In addition to direct emissions of RGM, correlations between GEM and RGM, can reveal whether RGM was mainly produced photochemically or directly emitted. Sillman et al. (2007) previously found that positive correlations between model-predicted concentrations of GEM and RGM indicated that RGM was directly emitted rather than produced by photochemical oxidation processes involving $\mathrm{O}_{3}, \mathrm{OH}, \mathrm{NO}_{\mathrm{x}}$, sulphur and halogens species, whereas a negative correlation suggested the latter mechanism dominated. As illustrated in Table 3b, the positive correlations between GEM and RGM during both summer seasons and fall 2006 would suggest direct emissions of RGM dominated over photochemical production of RGM. In other seasons, such as in fall 2005, winter 2006 and spring 2006, GEM-RGM correlation coefficients were close to zero. This lack of correlation between GEM and RGM means that both mechanisms of RGM production were possible.

In the Supplement (Fig. S1), two-day HYSPLIT back trajectories were also plotted for each season to provide further insight into the correlation analysis results. From the correlations with $\mathrm{PHg}$, potential sources of $\mathrm{PHg}$ may be from the absorption of gaseous $\mathrm{Hg}$ on re-suspended dust from crustal/soil (all seasons), road (winter), and agricultural activity (summer and fall), and point source dust emissions 
(all seasons). Back trajectories show that these are potential sources of PHg to the ELA site, since the trajectories passed over nearby sources of dust (see site description and Fig. 1). But there are uncertainties because of the potential deposition of particulate matter and the source of the absorbed mercury is unknown. The back trajectories might be more useful for confirming the influence of $\mathrm{Hg}$ point sources. Correlation results indicated RGM and $\mathrm{SO}_{2}$ were correlated in every season except winter 2006, which is supported by the relatively fewer trajectories passing over $\mathrm{Hg}$ point sources southeast of the ELA site (Fig. S1c) compared to other seasons. Slower moving trajectories passing over urban and industrial areas could suggest that RGM was formed by photochemical processes involving $\mathrm{O}_{3}$, since the precursors of $\mathrm{O}_{3}$ are typically emitted from urban and industrial areas and stagnant air masses are conducive to $\mathrm{O}_{3}$ formation (Logan, 1989). In the GEM-RGM correlations, none of the seasons were dominated by photochemical production of RGM, and this was reflected in the shorter (i.e., slower) back trajectories found in all seasons. But this interpretation of the back trajectories might not be applicable if other atmospheric oxidants are involved in the photochemical production of RGM.

\subsection{Principal components analysis (PCA)}

Six factors were generated when PCA was initially applied to the daily average data consisting of all the variables. The initial factor loadings (i.e., correlation coefficients between variables and factors) revealed that wind speed and total precipitation variables were not present in the factors that contained loadings for $\mathrm{Hg}$ and other pollutants. This suggests that these variables were not useful for characterizing potential sources of atmospheric Hg to the ELA. Therefore, PCA was applied again with all variables except wind speed and total precipitation and 4 factors were retained. The total variance explained by the four factors generated (denoted by PCA-1 to PCA-4) was $70.4 \%$, with $22.6 \%, 19 \%, 15.5 \%$ and $13.3 \%$ explained by PCA $1-4$, respectively.

PCA-1 had high factor loadings on GEM, $\mathrm{HNO}_{3}, \mathrm{~K}^{+}$, and $\mathrm{NH}_{4}^{+}, \mathrm{NO}_{3}^{-}$, and $\mathrm{SO}_{4}^{2-}$ (see Table 4). There were also moderate loadings on $\mathrm{SO}_{2}, \mathrm{O}_{3}$ and $\mathrm{Ca}^{2+}$. The pollutants with the most influence on this factor represent transport of industrial emissions or regional background pollution, as observed previously using correlation analyses. The presence of $\mathrm{K}^{+}$ in PCA-1 indicates wood combustion and biomass burning (e.g., wildfires) are potential sources, but this needs to be confirmed with other pollutant markers, such as carbon measurements (Choi et al., 2008; Huang et al., 2010, 2011) or levoglucosan (Watson et al., 2008).

PCA-2, which had high factor loadings on all three mercury species and $\mathrm{O}_{3}$, and negative loadings on relative humidity, may be related to strong pollution events associated with industrial and urban areas. This factor also had some minor loadings for $\mathrm{HNO}_{3}$ and $\mathrm{SO}_{2}$. The high factor loadings on RGM and $\mathrm{O}_{3}$, and negative loading on relative humidity,
Table 4. Factor loadings from Principal Components Analysis.

\begin{tabular}{|c|c|c|c|c|}
\hline & PCA-1 & PCA-2 & PCA-3 & PCA-4 \\
\hline GEM & 0.48 & 0.60 & & \\
\hline $\mathrm{PHg}$ & & 0.62 & 0.26 & 0.39 \\
\hline RGM & & 0.87 & & \\
\hline $\mathrm{SO}_{2}$ & 0.37 & 0.25 & & 0.29 \\
\hline $\mathrm{HNO}_{3}$ & 0.76 & 0.31 & 0.33 & \\
\hline $\mathrm{Ca}^{2+}$ & 0.32 & & 0.87 & \\
\hline $\mathrm{Mg}^{2+}$ & & & 0.92 & \\
\hline $\mathrm{K}^{+}$ & 0.53 & & 0.45 & \\
\hline $\mathrm{Na}^{+}$ & & & & 0.91 \\
\hline $\mathrm{Cl}^{-}$ & & & & 0.81 \\
\hline $\mathrm{NH}_{4}^{+}$ & 0.95 & & & \\
\hline $\mathrm{NO}_{3}^{-}$ & 0.65 & & & \\
\hline $\mathrm{SO}_{4}^{2-}$ & 0.88 & & & \\
\hline $\mathrm{O}_{3}$ & 0.31 & 0.80 & & \\
\hline Temperature & & & 0.57 & -0.58 \\
\hline Relative humidity & & -0.81 & -0.26 & \\
\hline$\%$ of variance explained & 22.6 & 19.0 & 15.5 & 13.3 \\
\hline
\end{tabular}

in PCA-2 were consistent with those obtained from the studies by Lynam and Keeler (2006) and Huang et al. (2010), who assigned the factor to photochemical or gas phase oxidation.

Even though $\mathrm{O}_{3}$ was the only atmospheric oxidant of gaseous mercury measured at the site, other oxidants such as $\mathrm{OH}, \mathrm{Br}$ and $\mathrm{Cl}$ may be involved in the photochemical production of RGM. Halogens can be emitted from coal-fired power plants; GEM oxidation by reactive halogen species is thus possible on a global scale (Keene et al., 1999; Seigneur and Lohman, 2008; Holmes et al., 2010) Aside from RGM and $\mathrm{O}_{3}$, high loadings on temperature and negative loadings on GEM and $\mathrm{NO}_{\mathrm{x}}$ were reported in previous studies (Liu et al., 2007; Huang et al., 2010). $\mathrm{HNO}_{3}$ was likely present in the factor because it is the ultimate sink for $\mathrm{NO}_{\mathrm{x}}$ (Wang and Shooter, 2001), which is typically emitted from industrial sources. The positive factor loadings on $\mathrm{SO}_{2}$ and RGM as an indication of coal combustion sources were also reported in other studies (Lynam and Keeler, 2006; Liu et al., 2007; Huang et al., 2010), and consistent with the correlation analysis results from this study. PCA-2 contained several sources/processes that could not be separated into individual factors. This suggests that these sources/processes may be occurring simultaneously.

PCA-3 contained a minor loading on PHg and strong loadings on $\mathrm{K}^{+}, \mathrm{Ca}^{2+}$ and $\mathrm{Mg}^{2+}$, which are components typical of crustal or soil sources. There is also a strong influence on this factor by temperature. The factor loadings on $\mathrm{PHg}$, $\mathrm{Na}^{+}$and $\mathrm{Cl}^{-}$in PCA-4 were consistent with absorption of gaseous $\mathrm{Hg}$ on road-salt particles as discussed in the correlation analysis results. The factor loading on $\mathrm{SO}_{2}$ is relatively weak compared to $\mathrm{Na}^{+}$and $\mathrm{Cl}^{-}$; therefore, it is not closely related to this factor. 
Table 5. Mean cluster centres from K-means cluster analysis.

\begin{tabular}{|c|c|c|c|c|c|}
\hline & KCA-1 & KCA-2 & KCA-3 & KCA-4 & KCA-5 \\
\hline $\operatorname{GEM}\left(\mathrm{ng} \mathrm{m}^{-3}\right)$ & 1.57 & 1.71 & 2.00 & 1.59 & 1.52 \\
\hline $\mathrm{PHg}\left(\mathrm{pg} \mathrm{m}^{-3}\right)$ & 9.11 & 6.56 & 5.45 & 7.28 & 3.35 \\
\hline $\operatorname{RGM}\left(\mathrm{pg} \mathrm{m}^{-3}\right)$ & 1.66 & 2.14 & 0.55 & 0.90 & 0.63 \\
\hline $\mathrm{SO}_{2}\left(\mu \mathrm{g} \mathrm{m}^{-3}\right)$ & 0.55 & 0.63 & 0.26 & 1.33 & 0.26 \\
\hline $\mathrm{HNO}_{3}\left(\mu \mathrm{g} \mathrm{m}^{-3}\right)$ & 0.12 & 0.69 & 0.70 & 0.77 & 0.19 \\
\hline $\mathrm{Ca}^{2+}\left(\mu \mathrm{g} \mathrm{m}^{-3}\right)$ & 0.05 & 0.39 & 0.09 & 1.63 & 0.09 \\
\hline $\mathrm{Mg}^{2+}\left(\mu \mathrm{g} \mathrm{m}^{-3}\right)$ & 0.03 & 0.08 & 0.01 & 0.23 & 0.02 \\
\hline $\mathrm{K}^{+}\left(\mu \mathrm{g} \mathrm{m}^{-3}\right)$ & 0.02 & 0.08 & 0.06 & 0.11 & 0.02 \\
\hline $\mathrm{Na}^{+}\left(\mu \mathrm{g} \mathrm{m}^{-3}\right)$ & 0.14 & 0.03 & 0.02 & 0.03 & 0.02 \\
\hline $\mathrm{Cl}^{-}\left(\mu \mathrm{g} \mathrm{m}^{-3}\right)$ & 0.10 & 0.02 & 0.02 & 0.02 & 0.01 \\
\hline $\mathrm{NH}_{4}^{+}\left(\mu \mathrm{g} \mathrm{m}^{-3}\right)$ & 0.11 & 0.78 & 2.57 & 0.85 & 0.20 \\
\hline $\mathrm{NO}_{3}^{-}\left(\mu \mathrm{g} \mathrm{m}^{-3}\right)$ & 0.25 & 0.59 & 4.59 & 2.07 & 0.17 \\
\hline $\mathrm{SO}_{4}^{2-}\left(\mu \mathrm{g} \mathrm{m}^{-3}\right)$ & 0.44 & 2.22 & 3.29 & 2.15 & 0.55 \\
\hline $\mathrm{O}_{3}(\mathrm{ppb})$ & 34.11 & 40.76 & 31.52 & 32.96 & 28.84 \\
\hline Temperature $\left({ }^{\circ} \mathrm{C}\right)$ & -8.44 & 13.92 & 8.35 & 13.70 & 5.85 \\
\hline Relative humidity (\%) & 69.95 & 66.07 & 82.32 & 69.87 & 74.23 \\
\hline \multicolumn{6}{|c|}{$\%$ of data in each cluster with concentrations $>75$ th percentile* } \\
\hline GEM & $19 \%$ & $58 \%$ & $100 \%$ & $33 \%$ & $16 \%$ \\
\hline $\mathrm{PHg}$ & $67 \%$ & $54 \%$ & $43 \%$ & $56 \%$ & $12 \%$ \\
\hline RGM & $61 \%$ & $66 \%$ & $14 \%$ & $44 \%$ & $16 \%$ \\
\hline
\end{tabular}

Mean cluster centres shown in bold were $>80$ th percentile value and were considered elevated.

* 75th percentile GEM, PHg and RGM was $1.7 \mathrm{ng} \mathrm{m}^{-3}, 6.09 \mathrm{pg} \mathrm{m}^{-3}$ and $1.07 \mathrm{pg} \mathrm{m}^{-3}$ respectively for the entire study period.

\subsection{K-means cluster analysis}

A five-cluster solution was chosen for K-means cluster analysis (KCA) after running the analysis with four and six clusters. The five-cluster solution was most ideal because the four PCA factors did not explain all of the variance in the data set; thus choosing five clusters might help to explain the remaining variance. The six-cluster solution contained two clusters that have similar profiles. The mean cluster centres shown in Table 5 were used to interpret the K-means clusters by identifying variables with high mean values (Masiol et al., 2010). The percentage of data with $>75$ th percentile GEM, $\mathrm{PHg}$ and RGM concentrations $\left(\mathrm{GEM}=1.7 \mathrm{ng} \mathrm{m}^{-3}, \mathrm{PHg}=\right.$ $6.09 \mathrm{pg} \mathrm{m}^{-3}$, and $\mathrm{RGM}=1.07 \mathrm{pg} \mathrm{m}^{-3}$ for the entire study period) were calculated for each cluster to determine which clusters were associated with elevated speciated atmospheric Hg concentrations.

KCA-1 contained large mean clusters centres for PHg, $\mathrm{Na}^{+}$, and $\mathrm{Cl}^{-}$, and lower mean temperatures (see Table 5), similar to the results obtained using correlation analysis and observed in PCA-4. This profile is likely related to winter road-salt particles, instead of sea-salt aerosols. KCA-2, which had high mean cluster centres for $\mathrm{PHg}, \mathrm{RGM}, \mathrm{SO}_{2}$, $\mathrm{HNO}_{3}, \mathrm{Ca}^{2+}, \mathrm{Mg}^{2+}, \mathrm{K}^{+}, \mathrm{NH}_{4}^{+}, \mathrm{NO}_{3}^{-}, \mathrm{SO}_{4}^{2-}$, and $\mathrm{O}_{3}$, may be related to photochemical production of RGM, since this was the only cluster where the mean cluster centres for RGM and $\mathrm{O}_{3}$ were elevated. The transport of industrial emissions as previously described was also apparent in KCA-3, which had high mean values for GEM, $\mathrm{HNO}_{3}, \mathrm{~K}^{+}, \mathrm{NH}_{4}^{+}, \mathrm{NO}_{3}^{-}$, and $\mathrm{SO}_{4}^{2-}$. The elevated $\mathrm{K}^{+}$and GEM concentrations may be attributed to wildfires and wood combustion (Watson et al., 2008; Huang et al., 2011). KCA-4 had elevated mean cluster centres for $\mathrm{PHg}, \mathrm{SO}_{2}, \mathrm{HNO}_{3}, \mathrm{Ca}^{2+}, \mathrm{Mg}^{2+}, \mathrm{K}^{+}, \mathrm{NH}_{4}^{+}, \mathrm{NO}_{3}^{-}$, and $\mathrm{SO}_{4}^{2-}$, which is similar to some of elevated components in KCA-2. But in KCA-4, the mean cluster centres for $\mathrm{SO}_{2}$, $\mathrm{Ca}^{2+}, \mathrm{Mg}^{2+}$, and $\mathrm{NO}_{3}^{-}$were higher than KCA-2. Thus, KCA-4 is classified as emissions from crustal or soil sources. The final cluster (KCA-5) depicted background pollution due to lower mean cluster centres for all variables (Masiol et al., 2010). The bottom of Table 5 illustrates the proportion of data with GEM, PHg, or RGM concentrations $>75$ th percentile (for the entire study) in each cluster. KCA-3 (transport of industrial emissions) had the largest percentage of elevated measurements of GEM, and the largest percentages of elevated $\mathrm{PHg}$ and RGM values were KCA-1 (road-salt particles) and KCA-2 (photochemical production of RGM), respectively.

\subsection{Hierarchical cluster analysis}

To compare the results with those obtained from Kmeans cluster analysis, five clusters were also chosen for 
Table 6. Mean cluster centres from hierarchical cluster analysis.

\begin{tabular}{|c|c|c|c|c|c|}
\hline & HCA-1 & HCA-2 & HCA-3 & $\mathrm{HCA}-4$ & HCA-5 \\
\hline $\operatorname{GEM}\left(\mathrm{ng} \mathrm{m}^{-3}\right)$ & 1.71 & 1.8 & 1.46 & 1.68 & 1.65 \\
\hline $\mathrm{PHg}\left(\mathrm{pg} \mathrm{m}^{-3}\right)$ & 4.56 & 4.88 & 2.8 & 6.19 & 7.29 \\
\hline $\operatorname{RGM}\left(\mathrm{pg} \mathrm{m}^{-3}\right)$ & 1.1 & 0.86 & 0.26 & 2.19 & 2.88 \\
\hline $\mathrm{SO}_{2}\left(\mu \mathrm{g} \mathrm{m}^{-3}\right)$ & 0.18 & 0.57 & 0.28 & 0.81 & 0.5 \\
\hline $\mathrm{HNO}_{3}\left(\mu \mathrm{g} \mathrm{m}^{-3}\right)$ & 0.34 & 0.93 & 0.17 & 0.67 & 0.22 \\
\hline $\mathrm{Ca}^{2+}\left(\mu \mathrm{g} \mathrm{m}^{-3}\right)$ & 0.14 & 0.26 & 0.1 & 0.81 & 0.05 \\
\hline $\mathrm{Mg}^{2+}\left(\mu \mathrm{g} \mathrm{m}^{-3}\right)$ & 0.03 & 0.04 & 0.02 & 0.15 & 0.02 \\
\hline $\mathrm{K}^{+}\left(\mu \mathrm{g} \mathrm{m}^{-3}\right)$ & 0.05 & 0.09 & 0.02 & 0.08 & 0.01 \\
\hline $\mathrm{Na}^{+}\left(\mu \mathrm{g} \mathrm{m}^{-3}\right)$ & 0.01 & 0.02 & 0.01 & 0.03 & 0.07 \\
\hline $\mathrm{Cl}^{-}\left(\mu \mathrm{g} \mathrm{m}^{-3}\right)$ & 0.01 & 0.02 & 0.01 & 0.01 & $\mathbf{0 . 0 3}$ \\
\hline $\mathrm{NH}_{4}^{+}\left(\mu \mathrm{g} \mathrm{m}^{-3}\right)$ & 0.31 & 1.97 & 0.2 & 0.55 & 0.16 \\
\hline $\mathrm{NO}_{3}^{-}\left(\mu \mathrm{g} \mathrm{m}^{-3}\right)$ & 0.17 & 1.64 & 0.22 & 0.85 & 0.18 \\
\hline $\mathrm{SO}_{4}^{2-}\left(\mu \mathrm{g} \mathrm{m}^{-3}\right)$ & 0.83 & 4.91 & 0.54 & 1.53 & 0.58 \\
\hline $\mathrm{O}_{3}(\mathrm{ppb})$ & 36.58 & 40.56 & 25.55 & 40.06 & 38.24 \\
\hline Temperature $\left({ }^{\circ} \mathrm{C}\right)$ & 12.8 & 11.68 & 5.16 & 14.89 & -6.42 \\
\hline Relative humidity (\%) & 68.57 & 82.51 & 76.3 & 63.22 & 58.42 \\
\hline \multicolumn{6}{|c|}{$\%$ of data in each cluster with concentrations $>75$ th percentile* } \\
\hline GEM & $63 \%$ & $69 \%$ & $3 \%$ & $43 \%$ & $40 \%$ \\
\hline $\mathrm{PHg}$ & $21 \%$ & $31 \%$ & $6 \%$ & $49 \%$ & $60 \%$ \\
\hline RGM & $43 \%$ & $46 \%$ & $4 \%$ & $66 \%$ & $70 \%$ \\
\hline
\end{tabular}

Mean cluster centres shown in bold were $>80$ th percentile value and were considered elevated.

* 75th percentile GEM, PHg and RGM was $1.7 \mathrm{ng} \mathrm{m}^{-3}, 6.09 \mathrm{pg} \mathrm{m}^{-3}$ and $1.07 \mathrm{pg} \mathrm{m}^{-3}$ respectively for the entire study period.

hierarchical cluster analysis (HCA) using Ward's method and squared euclidean distance measure. HCA-1 and HCA-2 have similar mean cluster centres for GEM, PHg and RGM (Table 6). Both clusters contained slightly elevated mean cluster centre for GEM relative to the overall average GEM concentration of $1.56 \mathrm{ng} \mathrm{m}^{-3}$, and the mean cluster centres for PHg and RGM were close to their respective overall averages $\left(4.42 \mathrm{pg} \mathrm{m}^{-3}\right.$ for PHg and $0.99 \mathrm{pg} \mathrm{m}^{-3}$ for RGM). The major difference between the two clusters was the higher mean cluster centres for all the other pollutant variables in HCA-2. More specifically, the variables representative of transport of combustion and industrial emissions (i.e., $\mathrm{SO}_{2}$, $\mathrm{HNO}_{3}, \mathrm{NH}_{4}^{+}, \mathrm{NO}_{3}^{-}, \mathrm{SO}_{4}^{2-}$ ) were elevated in HCA-2. Analysis of back trajectory plots for these two clusters could help differentiate the clusters (discussed in next section).

HCA-2 and KCA-3 have consistent mean cluster centres, but HCA-2 had elevated mean cluster centres for $\mathrm{SO}_{2}$ and $\mathrm{O}_{3}$. In addition to transport of industrial emissions, HCA-2 is attributed to transportation and coal and wood combustion emissions, which frequently emit volatile organic compounds, $\mathrm{CO}$ and $\mathrm{NO}_{2}$ that can lead to $\mathrm{O}_{3}$ formation. The mean cluster centres of HCA-3 were consistent with those of KCA-5, which represented background pollution. HCA4 consisted of elevated mean cluster centres for RGM, $\mathrm{SO}_{2}$, $\mathrm{HNO}_{3}, \mathrm{Ca}^{2+}, \mathrm{Mg}^{2+}, \mathrm{NH}_{4}^{+}, \mathrm{NO}_{3}^{-}, \mathrm{SO}_{4}^{2-}$, and $\mathrm{O}_{3}$. Although some of the variables identified as elevated in HCA-4 were similar to HCA-2, the main difference between the two clusters is the elevated mean cluster centres for RGM, $\mathrm{Ca}^{2+}$, $\mathrm{Mg}^{2+}$, and $\mathrm{O}_{3}$ in HCA-4. The elevated mean cluster centre for both $\mathrm{RGM}$ and $\mathrm{O}_{3}$ may be suggestive of photochemical production of RGM (consistent with KCA-2), and emissions from crustal/soil sources might have contributed to higher mean cluster centre for $\mathrm{PHg}$.

HCA-5 had high mean cluster centres for PHg, RGM, $\mathrm{Na}^{+}$ and $\mathrm{Cl}^{-}$, and low mean cluster centre for temperature, which was comparable to the KCA-1 cluster that was interpreted as road-salt particles containing previously-deposited $\mathrm{Hg}$. The bottom of Table 6 illustrates that HCA-2 (transport of industrial emissions) had the largest percentage of elevated GEM concentrations, while HCA-5 (road-salt particles) had the largest percentages for both PHg and RGM. The percentage of data with elevated RGM concentrations was fairly high $(66 \%)$ for HCA-4 as well.

\subsection{HYSPLIT back trajectories for K-means and Hierarchical clusters}

The two day back trajectories for each of the clusters classified using the K-means method and Hierarchical Ward's method are shown in Figs. 3 and 4, respectively. Back trajectories for KCA-1 (K-means cluster 1) shown in Fig. 3a mainly passed over northwestern Ontario and Manitoba in 

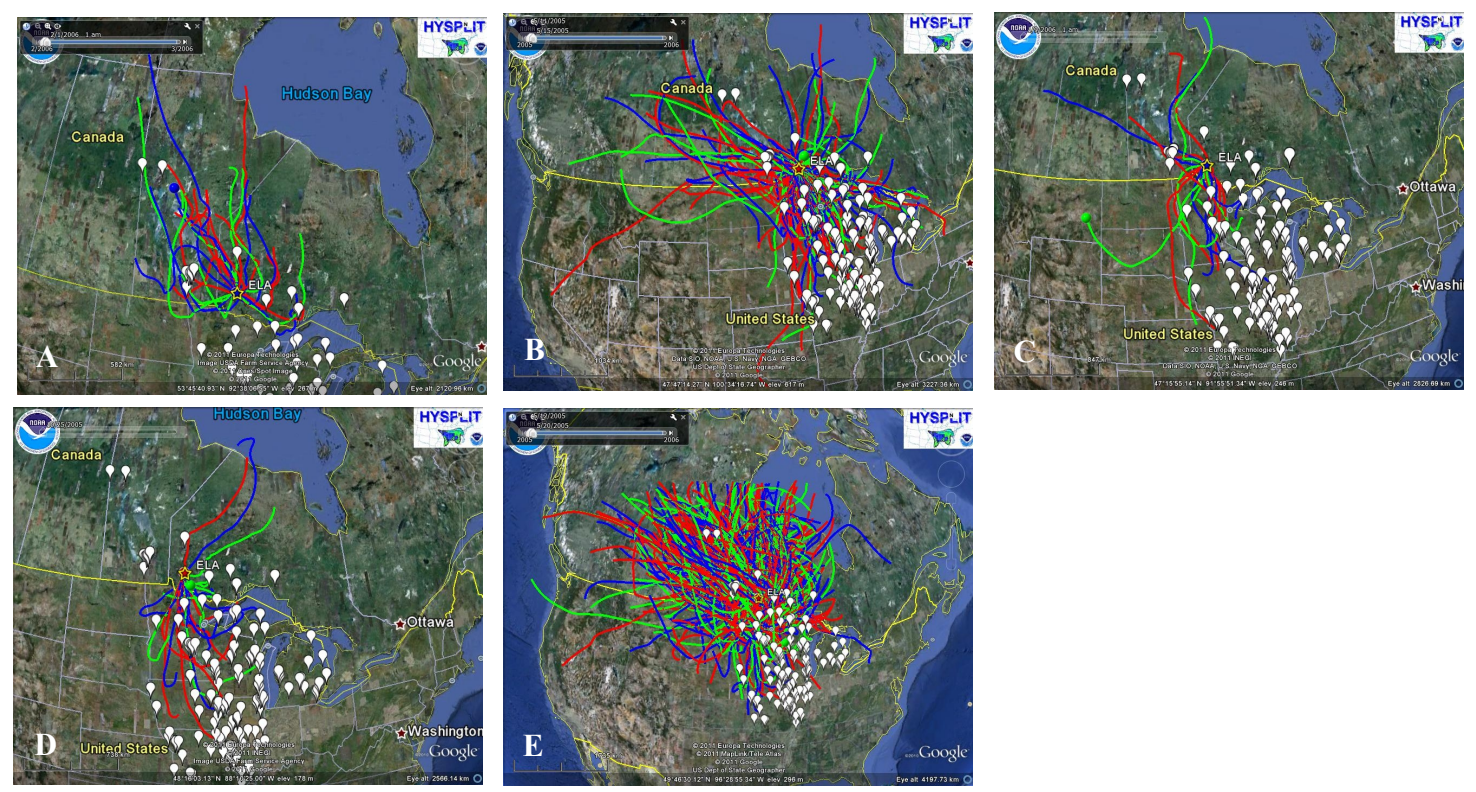

Fig. 3. Two-day HYSPLIT (NOAA ARL, 2011) back trajectories for K-means clusters. (A) KCA-1, (B) KCA-2, (C) KCA-3, (D) KCA-4, and (E) KCA-5. White placemarks represent $\mathrm{Hg}$ point sources.

Canada, which was consistent with the lower mean temperature for this cluster. Several trajectories traced back to fossil fuel power plants, metal and steel processing plants, and mining sites within Canada; however the majority of them did not encounter any $\mathrm{Hg}$ point sources. The contribution from road dust with salt components is a strong possibility because several trajectories passed over the Trans-Canada highway, which is approximately $15-20 \mathrm{~km}$ north and west of the ELA site. In Fig. 3b, the back trajectories for KCA-2 traced back to western Canada, areas north of the ELA site, and states located south and southeast of the ELA site, such as Minnesota, Iowa, Wisconsin, Illinois, and Michigan. The transport of PHg and RGM to the ELA site by the modeled air trajectory path may not be fully accurate due to the possibility of wet deposition. The $\mathrm{Hg}$ point sources in these states include power plants, paper mills, steel processing plants, and cement plants, and there are also urban areas that contribute to transportation emissions. $\mathrm{NO}_{\mathrm{x}}, \mathrm{CO}$ and hydrocarbons are typically emitted from these sources, which can contribute to formation of ground-level $\mathrm{O}_{3}$ and secondary organic aerosols.

Elevated tropospheric $\mathrm{O}_{3}$ concentrations have been observed in rural/remote areas downwind of urban and industrialized areas and persisted for several days covering an area over $500000 \mathrm{~km}^{2}$ (Logan, 1989). Since many of the trajectories from the south also appeared slower moving (i.e., shorter trajectory) than the trajectories from western Canada, the more stagnant air mass favours the buildup of $\mathrm{O}_{3}$, which could play a role in the oxidation of GEM to RGM. However, recent studies are examining other atmospheric oxidants and reaction mechanisms for gaseous mercury. Reactive halogen species are more likely to be responsible for the depletion and conversion of GEM to RGM based on measurements of atmospheric $\mathrm{Hg}, \mathrm{O}_{3}$ and $\mathrm{BrO}$ in marine environments (Peleg et al., 2007; Obrist et al., 2011), and models suggest that similar reactions with $\mathrm{Br}$ might also be occurring on a global scale (Seigneur and Lohman, 2008; Holmes et al., 2009, 2010). Seigneur and Lohman (2008) conducted interhemispheric simulations with different sets of $\mathrm{Br}$ reaction kinetics and found 20-40\% difference in the mean GEM concentrations using different reaction kinetics. The global atmospheric $\mathrm{Hg}$ model with $\mathrm{Br}$ chemistry by Holmes et al. (2010) was capable of producing averaged TGM measurements at polar regions and some MBL and land-based sites. Agreement between modeled and measured TGM concentrations at land-based sites in the Northern Hemisphere was found for both $\mathrm{Hg}+\mathrm{Br}$ and $\mathrm{Hg}+\mathrm{O}_{3} / \mathrm{OH}$ models (Holmes et al., 2010).

Back trajectories for KCA-3 are shown in Fig. 3c and mainly traced back to areas south of the ELA site, such as Minnesota and Wisconsin. Several trajectories were northwest of the ELA site and passed over power plants and steel processing plants in Winnipeg. Compared to the back trajectories for KCA-2, the trajectories for KCA-3 did not trace back to as many industrial and urban areas, which might have resulted in the lower average $\mathrm{O}_{3}$ and also $\mathrm{SO}_{2}$ concentrations. In Fig. 3d, the majority of the back trajectories for KCA-4, which represented emissions from crustal/soil sources and combustion and industrial sources, passed over Minnesota and Iowa, and a few trajectories traced back to remote areas northeast of the ELA site. The back trajectories for KCA-5 are shown in Fig. 3e. KCA-5 was associated with background pollution because of the lower mean cluster 

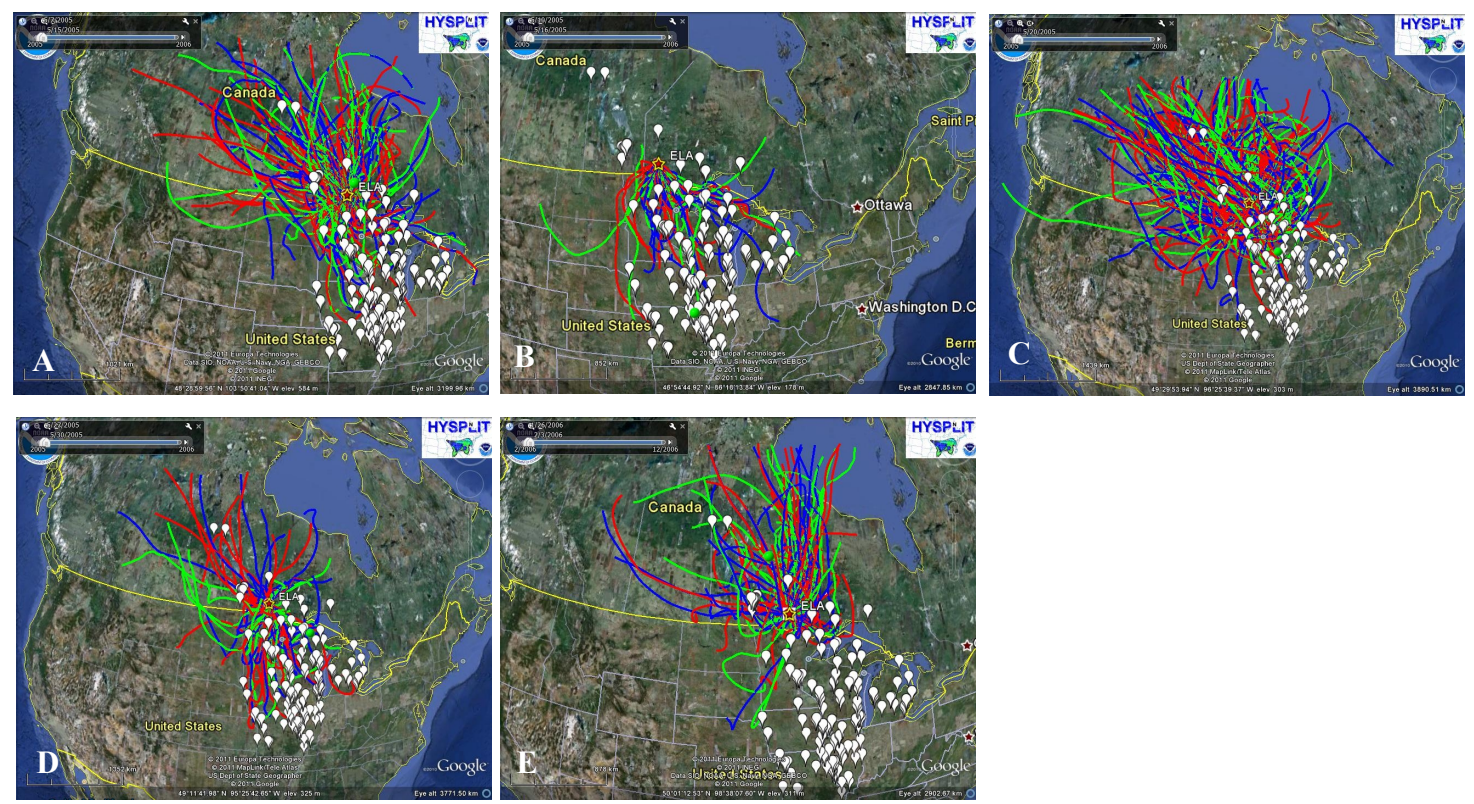

Fig. 4. Two-day HYSPLIT (NOAA ARL, 2011) back trajectories for Hierarchical clusters. (A) HCA-1, (B) HCA-2, (C) HCA-3, (D) HCA-4, and (E) HCA-5. White placemarks represent Hg point sources.

values for all the pollutants compared to other clusters and this interpretation is further supported by larger portion of trajectories that traced back to parts of northern and northwestern Canada compared to south of the ELA site. The transport of air masses from higher latitudes was also associated with lower factor scores for pollutant variables at the Detroit site (Liu et al., 2007).

In the analysis of the Hierarchical mean cluster centres, it was found that the mean for $\mathrm{Hg}$ species for HCA-1 and HCA2 (Hierarchical clusters 1 and 2) were similar, and mean cluster centres for all other pollutants were higher for HCA-2. Figure $3 \mathrm{a}$ and $\mathrm{b}$ illustrates the differences in the direction of the back trajectories for the two clusters. In HCA-1, the trajectories were northwest/north and south/southeast of the ELA site, whereas almost all of the trajectories in HCA-2 originated from south/southeast of the site where there is a higher density of $\mathrm{Hg}$ point sources. The trajectories for HCA-1 (Fig. 4a) appeared consistent with those for KCA-2 (Fig. 3b), which was associated with photochemical production of RGM. However, the mean values for these two clusters were not consistent as shown in Tables 5 and 6 . Some of the back trajectories for HCA-2 (Fig. 4b) were consistent with those for KCA-3 (Fig. 3c); specifically, both clusters have several trajectories that traced back to parts of Minnesota, Iowa and Missouri. Similarities on some of the trajectories were expected since elevated mean cluster centres for $\mathrm{GEM}, \mathrm{HNO}_{3}, \mathrm{NH}_{4}^{+}, \mathrm{NO}_{3}^{-}$, and $\mathrm{SO}_{4}^{2-}$ were identified in both clusters. Furthermore, the trajectories that extended to Wisconsin, Illinois and Michigan (southeast of the ELA site) in HCA-2 (Fig. 4b) were found in KCA-2 (Fig. 3b). The trajectories overlapped because the mean cluster centre for $\mathrm{O}_{3}$ was elevated in both clusters. The elevated $\mathrm{O}_{3}$ concentration was likely because the trajectories passed over major $\mathrm{Hg}$ point sources, urban areas and wood combustion/wildfire locations that contributed to $\mathrm{CO}, \mathrm{NO}_{\mathrm{x}}$, and volatile organic compound emissions. Back trajectories for HCA-3 (Fig. 4c) were similar to those for KCA-5 (Fig. 3e) in terms of the large proportion of trajectories from northern Canada. The back trajectories for HCA-4 shown in Fig. 4d originated from northwest and south of the ELA site and appeared consistent with some of the trajectories for KCA-2 (Fig. 3b), KCA-4 (Fig. 3d) and KCA-5 (Fig. 3e). The presence of some of the trajectories for KCA-2 in HCA-4 was expected because of the elevated RGM and $\mathrm{O}_{3}$ mean cluster centres in both clusters. Elevated mean values for $\mathrm{SO}_{2}, \mathrm{Ca}^{2+}, \mathrm{Mg}^{2+}$ and $\mathrm{K}^{+}$ were observed in both HCA-4 and KCA-4. Finally, the back trajectories for HCA-5 shown in Fig. 4e mainly traced back to areas north of the ELA site, which was most consistent with the trajectory results for the K-means cluster assigned to road-salt particles (KCA-1 in Fig. 3a). Compared to KCA1 , there were more trajectories in HCA-5 extending back to Hudson Bay, and some passed over western Canada and midwest region of the United States.

The trajectories shown for the hierarchical clusters in Fig. 4 were similar to some of the trajectories belonging to several K-means clusters in Fig. 3. This led to some differences in the trajectory plots for the two cluster methods even though they represented the same cluster based on the mean cluster centres in Tables 5 and 6 . The clusters generated from both methods often represented several sources 
and processes (e.g., industrial/combustion emissions, photochemical production of RGM, and/or crustal or soil emissions). One possible reason for the discrepancy can be attributed to differences in the theoretical approaches of the two cluster analysis techniques (Viana et al., 2008), e.g., different clustering algorithm and distance/linkage measures. Another reason might be because these sources and processes are occurring simultaneously and could not be separated out in the data and hence, in the trajectory plots as well.

\section{Conclusions}

A data set consisting of major ions and trace gases in particulate matter, ground-level ozone concentrations and meteorological variables were analyzed to explain seasonal and diurnal variations in speciated atmospheric $\mathrm{Hg}$ concentrations and to identify potential sources affecting speciated atmospheric $\mathrm{Hg}$ concentrations at the remote Experimental Lakes Area site. To identify potential sources of atmospheric $\mathrm{Hg}$ to the site, receptor modelling approaches including correlation analysis, principal component analysis, cluster Analysis using K-means and Hierarchical methods, and HYSPLIT back trajectory modelling were applied. Multiple receptor data analysis and modelling approaches were used to reveal consistency and discrepancy in the results and interpretation of source-receptor relationships for speciated atmospheric $\mathrm{Hg}$.

Analysis of seasonal variability revealed that the season with highest GEM and RGM concentrations coincided with highest $\mathrm{O}_{3}$ concentrations. The highest $\mathrm{PHg}$ concentrations occurred in seasons with highest $\mathrm{SO}_{2}$ and $\mathrm{Na}^{+}$concentrations and during both warm and cold seasons. Changes in temperature and relative humidity strongly affected the diurnal variability of GEM concentrations, whereas a lesser affect of these variables were observed on the diurnal variability of PHg and RGM.

Correlation coefficients between pollutant variables related to several source origins were examined. In winter, strong correlations were found between $\mathrm{PHg}, \mathrm{Na}^{+}, \mathrm{Cl}^{-}$and $\mathrm{Mg}^{2+}$, which suggested road-salt particles as a surface for absorption of gaseous $\mathrm{Hg}$. In the other seasons, strong correlations indicative of combustion sources, transport of industrial emissions, emissions of previously-deposited mercury from crustal, soil and agricultural activities, and photochemical production of RGM were identified. The main advantage of correlation analysis was that it can be applied to a data set with smaller number of measurements, e.g., seasonal data. Aside from the transport of industrial emissions, the sources identified in this study were dependent on the season.

PCA generated four factors that were similar to the potential source origins identified in correlation analysis. Compared with correlation analysis, PCA was a more appropriate technique for analyzing multiple pollutant variables at once, but required a large number of measurements. Hence, this technique was only applied to the data set covering the entire study period. The PCA factors were consistent with the clusters generated from K-means cluster analysis; however, there was an additional group that was representative of background pollution in the K-means and Hierarchical methods. In cluster analysis, the clusters were representative of the entire data set, but in PCA only a portion of the entire data set was represented. In this study, the four PCA factors explained $\sim 70 \%$ of the variance in the data set, while the remaining $\sim 30 \%$ was the unexplained variance.

Through the use of back trajectories using the HYSPLIT model, it was revealed that even a remote site like the ELA is affected by distant $\mathrm{Hg}$ point sources. For the clusters related to transport of industrial and combustion emissions and photochemical production of RGM involving ground-level $\mathrm{O}_{3}$, many of the back trajectories traced back to distant point sources, such as power plants, metal and steel processing plants, paper mills and cement plants located in Canada and United States, and urban areas in the mid-west US region. The cluster associated with road-salt particles from the Kmeans and Hierarchical methods both have trajectories tracing back to areas north of the ELA site, which was in the direction of the Trans-Canada highway. Trajectory plots were also consistent between the K-means and Hierarchical clusters associated with background pollution.

The discrepancies between the K-means and Hierarchical method were the clusters related to industrial/combustion emissions, photochemical production of RGM, and crustal/soil emissions. This may be attributed to the different clustering algorithm and distance/linkage measures. Although it was possible to discriminate between these source origins by examining the mean cluster centres for specific variables that were elevated, the trajectory plots for the Hierarchical clusters were similar to some of the trajectories belonging to several K-means clusters. This likely occurred because the variables indicative of industrial/combustion emissions were elevated in at least two or more of the clusters. That is, the transport of industrial/combustion emissions was often occurring simultaneously with photochemical production of RGM or crustal/soil emissions, suggesting this type of source was a constant influence on atmospheric $\mathrm{Hg}$ concentrations at ELA site.

The data obtained for this study was not ideal for identifying specific types of industrial or combustion emissions, since secondary pollutants, such as nitrate and sulphate, could have originated from various primary sources (Hopke and Cohen, 2011). To investigate further into the exact types of industrial or combustion emissions using PCA or cluster analysis techniques, receptor measurements of trace metals and organic carbon concentrations are necessary. While $\mathrm{O}_{3}$ was used to suggest potential photochemical oxidation of GEM to RGM, future measurements should include $\mathrm{OH}$ and reactive halogen species since they may also be important atmospheric oxidants of Hg. Recent studies suggest other oxidants (e.g., $\mathrm{Br}, \mathrm{BrO}$ ) are potentially important in regions with active bromine chemistry, such as polar regions and MBL 
(Holmes et al., 2009; Obrist et al., 2011), and on a global scale (Holmes et al., 2010). In addition to data requirements, further research is needed on the use of a wider variety of receptor-based techniques for studying the source-receptor relationships of speciated atmospheric mercury, as this study demonstrated that these techniques have their strengths and weaknesses, which affects how sources of speciated atmospheric mercury are interpreted.

\section{Supplementary material related to this article is available online at: http://www.atmos-chem-phys.net/12/1903/2012/ acp-12-1903-2012-supplement.pdf.}

Acknowledgements. We greatly appreciate Ken Sandilands, Michael Tate and Frank McCann of University of Alberta for their help in the collection of mercury data at ELA, Amy Hou of Environment Canada, Ken Beaty of Department of Fisheries and Oceans, and Sandy Radecki of Ontario Climate Centre for their assistance with extracting archived data for this site. The agencies/organizations responsible for data contributions in 2005-2006 to the NatChem Particulate Matter Database, NAPS data and Ontario Climate Centre include Environment Canada and Department of Fisheries and Oceans. The authors also gratefully acknowledge the NOAA Air Resources Laboratory (ARL) for the provision of the HYSPLIT transport and dispersion model and/or READY website (http://www.arl.noaa.gov/ready.php) used in this publication. Finally, we thank the reviewers for providing feedback that helped improve the manuscript.

Edited by: F. Yu

\section{References}

Abbott, M. L., Lin, C.-J., Martian, P., and Einerson, J. J.:. Atmospheric mercury near Salmon Falls Creek Reservoir in southern Idaho, Appl. Geochem., 23, 438-453, 2008.

Amos, H. M., Jacob, D. J., Holmes, C. D., Fisher, J. A., Wang, Q., Yantosca, R. M., Corbitt, E. S., Galarneau, E., Rutter, A. P., Gustin, M. S., Steffen, A., Schauer, J. J., Graydon, J. A., Louis, V. L. St., Talbot, R. W., Edgerton, E. S., Zhang, Y., and Sunderland, E. M.: Gas-particle partitioning of atmospheric $\mathrm{Hg}$ (II) and its effect on global mercury deposition, Atmos. Chem. Phys., 12, 591-603, doi:10.5194/acp-12-591-2012, 2012.

Arkian, F., Meshkatee, A.-H., and Bidokhti, A. A.: The effects of large-scale atmospheric flows on berylium-7 activity concentration in surface air, Environ. Monit. Assess., 168, 429-439, doi:10.1007/s10661-009-1124-1, 2010.

Baya, A. P. and Van Heyst, B.: Assessing the trends and effects of environmental parameters on the behaviour of mercury in the lower atmosphere over cropped land over four seasons, Atmos. Chem. Phys., 10, 8617-8628, doi:10.5194/acp-10-8617-2010, 2010.

Brooks, S., Luke, W., Cohen, M., Kelly, P., Lefer, B., and Rappenglu, B.,: Mercury species measured atop the Moody Tower TRAMP site, Houston, Texas, Atmos. Environ., 44, 4045-4055, 2010.
Bullock, O. R.: Current methods and research strategies for modeling atmospheric mercury, Fuel Process. Technol., 65-66, 459471, 2000.

Bullock, O. R. and Brehme, K. A.: Atmospheric mercury simulation using the CMAQ model: Formulation description and analysis of wet deposition results, Atmos. Environ., 36, 2135-2146, 2002.

Bullock, O. R., Atkinson, D., and Braverman, T.: The North American mercury model intercomparison study (NAMMIS): study description and model-to-model comparisons, J. Geophys. Res., 113, D17310, doi:10.1029/2008JD009803, 2008.

Canadian National Atmospheric Chemistry Particulate Matter Database for 2005-2006 (NatChem), Environment Canada, Science and Technology Branch, 4905 Dufferin Street, Toronto, Ontario, Canada M3H 5T4, 2010.

Carpi, A.: Mercury from Combustion Sources: A Review of the Chemical Species Emitted and Their Transport in the Atmosphere, Water Air Soil Pollut., 98, 241-254, doi:10.1023/A:1026429911010, 1997.

Cheng, I., Lu, J., and Song, X.: Studies of Potential Sources that Contributed to Atmospheric Mercury in Toronto, Canada, Atmos. Environ., 43, 6145-6158, 2009.

Choi, H.-D., Holsen, T. M., and Hopke, P. K.: Atmospheric Mercury $(\mathrm{Hg})$ in the Adirondacks: Concentrations and Sources, Environ. Sci. Technol., 42, 5644-5653, 2008.

Christensen, J. H., Brandt, J., Frohn, L. M., and Skov, H.: Modelling of Mercury in the Arctic with the Danish Eulerian Hemispheric Model, Atmos. Chem. Phys., 4, 2251-2257, doi:10.5194/acp-4-2251-2004, 2004.

Cobbett, F. D. and Van Heyst, B. J.: Measurements of GEM fluxes and atmospheric mercury concentrations (GEM, RGM and Hgp) from an agricultural field amended with biosolids in Southern Ont., Canada (October 2004-November 2004), Atmos. Environ., 41, 2270-2282, 2007.

Dastoor, A. P. and Larocque, Y.: Global circulation of atmospheric mercury: a modelling study, Atmos. Environ., 38, 147-161, 2004.

Draxler, R. R. and Rolph, G. D.: HYSPLIT Model. Access via NOAA ARL READY Website. NOAA Air Resources Laboratory, Silver Spring, MD, available at: http://www.arl.noaa.gov/ ready/hysplit4.html (last access: 20 February 2011), 2003.

Du, S. and Rodenburg, L. A.: Source identification of atmospheric PCBs in Philadelphia/Camden using positive matrix factorization followed by the potential source contribution function, Atmos. Environ., 41, 8596-8608, 2007.

Edgerton, E. and Jansen, J.: Operation of dual mercury speciation analyzers at a site in the southeastern U.S., 10th International Conference on Mercury as a Global Pollutant, 24-29 July 2011, Halifax, Nova Scotia, Canada, Abstract RS1-O3, 2011.

Engle, M. A., Tate, M. T., Krabbenhoft, D. P., Kolker, A., Olson, M. L., Edgerton, E. S., DeWild, J. F., and McPherson, A. K.: Characterization and cycling of atmospheric mercury along the central US Gulf Coast, Appl. Geochem., 23, 419-437, doi:10.1016/j.apgeochem.2007.12.024, 2008.

Environment Canada: National Pollutant Release Inventory, available at: http://www.ec.gc.ca/inrp-npri/default.asp?lang= En $\backslash \& n=4 A 577 B B 9-1$ (last access: 15 December 2010), 2010.

Experimental Lakes Area (ELA): available at: http://www. experimentallakesarea.ca/ELA_Website.html (last access: 15 
March 2011), 2010.

Fiore, A., Jacob, D. J., Liu, H., Yantosca, R. M., Fairlie, T. D., and Li, Q.: Variability in surface ozone background over the United States: Implications for air quality policy, J. Geophys. Res., 108, 4787, doi:10.1029/2003JD003855, 2003.

Gabriel, M. C., Williamson, D. G., Brooks, S., and Lindberg, S.: Atmospheric speciation of mercury in two contrasting southeastern US airsheds, Atmos. Environ., 39, 4947-4958, 2005.

Gbor, P. K., Wen, D., Meng, F., Yang, F., Zhang, B., and Sloan, J. J.: Improved model for mercury emission, transport and deposition, Atmos. Environ., 40, 973-983, 2006.

Gustin, M. S. and Jaffe, D.: Reducing the uncertainty in measurement and understanding of mercury in the atmosphere, Environ. Sci. Technol., 44, 2222-2227, 2010.

Hall, B. D., Olson, M. L., Rutter, A. P., Frontiera, R. R., Krabbenhoft, D. P., Gross, D. S., Yuen, M., Rudolph, T. M., and Schauer, J.J.: Atmospheric mercury speciation in Yellowstone National Park, Sci. Total. Environ., 367, 354-366, 2006.

Han, Y.-J., Holsen, T. M., Hopke, P. K., and Yi, S.-M.: Comparison between Back-Trajectory Based Modeling and Lagrangian Backward Dispersion Modeling for Locating Sources of Reactive Gaseous Mercury, Environ. Sci. Technol., 39, 1715-1723, 2005.

Han, Y.-J., Holsen, T. M., and Hopke, P. K.: Estimation of source locations of total gaseous mercury measured in New York State using trajectory-based models, Atmos. Environ., 41, 6033-6047, 2007.

Holmes, C. D., Jacob, D. J., Mason, R. P., and Jaffe, D. A.: Sources and deposition of reactive gaseous mercury in the marine atmosphere, Atmos. Environ., 43, 2278-2285, 2009.

Holmes, C. D., Jacob, D. J., Corbitt, E. S., Mao, J., Yang, X., Talbot, R., and Slemr, F.: Global atmospheric model for mercury including oxidation by bromine atoms, Atmos. Chem. Phys., 10, 12037-12057, doi:10.5194/acp-10-12037-2010, 2010.

Hopke, P. K.: Recent developments in receptor modeling. J. Chemom., 17, 255-265, 2003.

Hopke, P. K. and Cohen, D. D.: Application of receptor modeling methods, Atmos. Pollut. Res., 2, 122-125, 2011.

Huang, J., Choi, H.-D., Hopke, P. K., and Holsen, T. M.: Ambient Mercury Sources in Rochester, NY: Results from Principle Components Analysis (PCA) of Mercury Monitoring Network Data, Environ. Sci. Technol., 44, 8441-8445, 2010.

Huang, J., Hopke, P. K., Choi, H.-D., Laing, J. R., Cui, H., Zananski, T. J., Chandrasekaran, S. R., Rattigan, O. V., and Holsen, T. M.: Mercury ( $\mathrm{Hg}$ ) emissions from domestic biomass combustion for space heating, Chemosphere, 84, 1694-1699, 2011.

Kabashnikov, V. P., Chaikovsky, A. P., Kucsera, T. L., and Metelskaya, N. S.: Estimated accuracy of three common trajectory statistical methods, Atmos. Environ., 45, 5425-5430, 2011.

Keeler, G. J., Landis, M. S., Norris, G. A., Christianson, E. M., and Dvonch, J.T.: Sources of mercury wet deposition in Eastern Ohio, USA, Environ. Sci. Technol., 40, 5874-5881, 2006.

Keene, W. C., Khalil, M. A. K., Erickson III, D. J., McCulloch, A., Graedel, T. E., Lobert, J. M., Aucott, M. L., Gong, S. L., Harper, D. B., Kleiman, G., Midgley, P., Moore, R. M., Seuzaret, C., Sturges, W. T., Benkovitz, C. M., Koropalov, V., Barrie, L. A., and Li, Y. F.: Composite global emissions of reactive chlorine from natural and anthropogenic sources: Reactive Chlorine Emissions Inventory, J. Geophys. Res., 104, 8429-8440, 1999.
Lee, J. H. and Hopke, P. K.:Apportioning sources of PM2.5 in St. Louis, MO using speciation trends network data, Atmos. Environ., 40, S360-S377, 2006.

Lee, S. and Ashbaugh, L.: Comparison of multi-receptor and single-receptor trajectory source apportionment (TSA) methods using artificial sources, Atmos. Environ., 41, 1119-1127, 2007.

Li, J., Sommar, J., Wängberg, I., Lindqvist, O., and Wei, S.Q.: Short-time variation of mercury speciation in the urban of Göteborg during GÖTE-2005, Atmos. Environ., 42, 8382-8388, 2008.

Lin, C.-J., Pan, L., Streets, D. G., Shetty, S. K., Jang, C., Feng, X., Chu, H.-W., and Ho, T. C.: Estimating mercury emission outflow from East Asia using CMAQ-Hg, Atmos. Chem. Phys. 10, 1853-1864, doi:10.5194/acp-10-1853-2010, 2010.

Lin, X. and Tao, Y.: A numerical modelling study on regional mercury budget for eastern North America, Atmos. Chem. Phys., 3, 535-548, doi:10.5194/acp-3-535-2003, 2003.

Lindberg, S. E. and Stratton, W. J.: Atmospheric mercury speciation: concentrations and behavior of reactive gaseous mercury in ambient air, Enviro. Sci. Technol., 32, 49-57, 1998.

Liu, B., Keeler, G. J., Dvonch, J. T., Barres, J. A., Lynam, M. M., Marsik, F. J., and Morgan, J. T.: Temporal variability of mercury speciation in urban air, Atmos. Environ., 41, 1911-1923, 2007.

Liu, B., Keeler, G. J., Dvonch, J. T., Barres, J. A., Lynam, M. M., Marsik, F. J., and Morgan, J. T.: Urban-rural differences in atmospheric mercury speciation, Atmos. Environ., 44, 2013-2023, 2010.

Logan, J. A.: Ozone in rural areas of the United States. J. Geophys. Res., 94, 8511-8532, 1989.

Lohman, K., Seigneur, C., Gustin, M., and Lindberg, S.: Sensitivity of the global atmospheric cycle of mercury to emissions, Appl Geochem., 23, 454-466, 2008.

Lu, J. Y., Schroeder, W. H., Barrie, L. A., Steffen, A., Welch, H. E., Martin, K., Lockhart, L., Hunt, R. V., Boila, G., and Richter, A.: Magnification of atmospheric mercury deposition to polar regions in springtime: the link to tropospheric ozone depletion chemistry, Geophys. Res. Lett., 28, 3219-3222, 2001.

Lynam, M. M. and Keeler, G. J.: Artifacts associated with the measurement of particulate mercury in an urban environment: The influence of elevated ozone concentrations, Atmos. Environ., 39, 3081-3088, 2005.

Lynam, M. M. and Keeler, G. J.: Source-receptor relationships for atmospheric mercury in urban Detroit, Michigan. Atmos. Environ., 40, 3144-3155, 2006.

Lyman, S. N. and Gustin, M. S.: Speciation of atmospheric mercury at two sites in northern Nevada, USA, Atmos. Environ., 42, 927 939, 2008.

Lyman, S. N., Jaffe, D. A., and Gustin, M. S.: Release of mercury halides from $\mathrm{KCl}$ denuders in the presence of ozone, Atmos. Chem. Phys., 10, 8197-8204, doi:10.5194/acp-10-81972010, 2010.

Malcolm, E. G. and Keeler, G. J.: Evidence for a sampling artifact for particulate-phase mercury in the marine atmosphere, Atmos. Environ., 41, 3352-3359, 2007.

Malcolm, E. G., Ford, A. C., Redding, T. A., Richardson, M. C., Strain, B. M., and Tetzner, S. W.: Experimental investigation of the scavenging of gaseous mercury by sea salt aerosol, J. Atmos. Chem., 63, 221-234, doi:10.1007/s10874-010-9165-y, 2009.

Manolopoulos, H., Schauer, J. J., Purcell, M. D., Rudolph, T. M., 
Olson, M. L., Rodger, B., and Krabbenhoft, D. P.: Local and regional factors affecting atmospheric mercury speciation at a remote location, J. Environ. Eng. Sci., 6, 491-501, 2007.

Masiol, M., Rampazzo, G., Ceccato, D., Squizzato, S., and Pavoni, B.: Characterization of $\mathrm{PM}_{10}$ sources in a coastal area near Venice (Italy): An application of factor-cluster analysis, Chemosphere 80, 771-778, 2010.

Mouli, P. C., Mohan, S. V., and Reddy, S. J.: Rainwater chemistry at a regional representative urban site: influence of terrestrial sources on ionic composition, Atmos. Environ., 39, 999-1008, 2005.

National Air Pollution Surveillance data for 2005-2006 (NAPS), Environment Canada, Science and Technology Branch, 4905 Dufferin Street, Toronto, Ontario, Canada M3H 5T4, 2011.

Obrist, D., Tas, E., Peleg, M., Matveev, V., Faïn, X., Asaf, D., and Luria, M.: Bromine-induced oxidation of mercury in the mid-latitude atmosphere, Nat. Geosci., 4, 22-26, doi:10.1038/ngeo1018, 2011.

Ontario Climate Centre data for 2005-2006, Environment Canada, Ontario Climate Centre, 4905 Dufferin Street, Toronto, Ontario, Canada M3H 5T4, 2010.

Pallant, J.: SPSS Survival Manual, second ed. Open University Press, Berkshire, UK (Chapter 15), 2005.

Peleg, M., Matveev, V., Tas, E., Luria, M., Valente, R. J., and Obrist, D.: Mercury depletion events in the troposphere in mid-latitudes at the Dead Sea, Israel, Environ. Sci. Technol., 41, 7280-7285, doi:10.1021/es070320j, 2007.

Pervez, S., Balakrishna, G., and Tiwari, S.: Source apportionment of mercury in dust fallout at urban residential area of Central India, Atmos. Chem. Phys. Discuss., 9, 21915-21940, doi:10.5194/acpd-9-21915-2009, 2009.

Pirrone, N., Cinnirella, S., Feng, X., Finkelman, R. B., Friedli, H. R., Leaner, J., Mason, R., Mukherjee, A. B., Stracher, G. B., Streets, D. G., and Telmer, K.: Global mercury emissions to the atmosphere from anthropogenic and natural sources, Atmos. Chem. Phys., 10, 5951-5964, doi:10.5194/acp-10-59512010, 2010.

Poissant, L., Pilote, M., Xu, X., and Zhang, H.: Atmospheric mercury speciation and deposition in the Bay St. François wetlands, J. Geophys. Res., 109, D11301, doi:10.1029/2003JD004364, 2004.

Poissant, L., Pilote, M., Beauvais, C., Constant, P., and Zhang, H. H.: A year of continuous measurements of three atmospheric mercury species (GEM, RGM and Hgp) in southern Quebec, Canada, Atmos. Environ., 39, 1275-1287, 2005.

Pongprueksa, P., Lin, C.-J., Lindberg, S. E., Jang, C., Braverman, T., Bullock, O. R., Ho, T. C., and Chu, H.-W.: Scientific uncertainties in atmospheric mercury models III: Boundary and initial conditions, model grid resolution, and $\mathrm{Hg}$ (II) reduction mechanism, Atmos. Environ., 42, 1828-1845, 2008.

Prendes, P., Andrade, J. M., López-Mahía, P., and Prada, D.: Source apportionment of inorganic ions in airborne urban particles from Coruña city (N.W. of Spain) using positive matrix factorization, Talanta, 49, 165-178, 1999.

Rolph, G. D.: Real-time Environmental Applications and Display System (READY), Website, NOAA Air Resources Laboratory, Silver Spring, MD, available at: http://www.arl.noaa.gov/ready/ hysplit4.html (last access: 20 February 2011), 2003.

Rothenberg, S. E., McKee, L., Gilbreath, A., Yee, D., Connor, M., and $\mathrm{Fu}, \mathrm{X}$.: Evidence for short-range transport of atmospheric mercury to a rural, inland site, Atmos. Environ., 44, 1263-1273, 2010.

Rúa, A., Hernández, E., de las Parras, J., Martín, I., Gimeno, L.: Sources of $\mathrm{SO}_{2}, \mathrm{SO}_{4}^{2-}, \mathrm{NO}_{\mathrm{x}}$, and $\mathrm{NO}_{3}$ in the air of four Spanish remote stations, J. Air Waste Manage., 48, 838-845, 1998.

Rutter, A. P., Snyder, D. C., Stone, E. A., Schauer, J. J., GonzalezAbraham, R., Molina, L. T., Márquez, C., Cárdenas, B., and de Foy, B.: In situ measurements of speciated atmospheric mercury and the identification of source regions in the Mexico City Metropolitan Area, Atmos. Chem. Phys., 9, 207-220, doi:10.5194/acp-9-207-2009, 2009.

Ryaboshapko, A., Bullock Jr., O. R., Christensen, J., Cohen, M., Dastoor, A., Ilyin, I., Petersen, G., Syrakov, D., Artz, R. S., Davignon, D., Draxler, R. R., and Munthe, J.: Intercomparison study of atmospheric mercury models: 1 . Comparison of models with short-term measurements, Sci. Total. Environ., 376, 228 240, 2007.

Scheifinger, H. and Kaiser, A.: Validation of trajectory statistical methods, Atmos. Environ., 41, 8846-8856, 2007.

Schroeder, W. H. and Munthe, J.: Atmospheric mercury - an overview, Atmos. Environ., 32, 809-822, 1998.

Seigneur, C. and Lohman, K.: Effect of bromine chemistry on the atmospheric mercury cycle, J. Geophys. Res., 113, D23309, doi:10.1029/2008JD010262, 2008.

Selin, N. E., Jacob, D. J., Park, R. J., Yantosca, R. M., Strode, S., Jaeglé, L., and Jaffe, D.: Chemical cycling and deposition of atmospheric mercury: Global constraints from observations, J. Geophys. Res., 112, D02308, doi:10.1029/2006JD007450, 2007.

Sigler, J. M., Mao, H., and Talbot, R.: Gaseous elemental and reactive mercury in Southern New Hampshire, Atmos. Chem. Phys., 9, 1929-1942, doi:10.5194/acp-9-1929-2009, 2009.

Sillman, S., Marsik, F. J., Al-Wali, K. I., Keeler, G. J., and Landis, M. S.: Reactive mercury in the troposphere: model formation and results for Florida, the northeastern United States, and the Atlantic Ocean, J. Geophys. Res., 112, D23305, doi:10.1029/2006JD008227, 2007.

Song, X., Cheng, I., and Lu, J.: Annual atmospheric mercury species in downtown Toronto, Canada, J. Environ. Monit., 11, 660-669, 2009.

Sprovieri, F., Hedgecock, I. M., and Pirrone, N.: An investigation of the origins of reactive gaseous mercury in the Mediterranean marine boundary layer, Atmos. Chem. Phys., 10, 3985-3997, doi:10.5194/acp-10-3985-2010, 2010a.

Sprovieri, F., Pirrone, N., Ebinghaus, R., Kock, H., and Dommergue, A.: A review of worldwide atmospheric mercury measurements, Atmos. Chem. Phys., 10, 8245-8265, doi:10.5194/acp10-8245-2010, 2010b.

StatSoft, Inc.: Electronic Statistics Textbook. Tulsa, OK, available at: http://www.statsoft.com/textbook/ (last access: 15 March 2011), 2011, (Printed Version): Hill, T. and Lewicki, P.: STATISTICS: Methods and Applications, StatSoft, Tulsa, OK, 2007.

Steffen, A., Douglas, T., Amyot, M., Ariya, P., Aspmo, K., Berg, T., Bottenheim, J., Brooks, S., Cobbett, F., Dastoor, A., Dommergue, A., Ebinghaus, R., Ferrari, C., Gardfeldt, K., Goodsite, M. E., Lean, D., Poulain, A. J., Scherz, C., Skov, H., Sommar, J., and Temme, C.: A synthesis of atmospheric mercury depletion event chemistry in the atmosphere and snow, Atmos. Chem. Phys., 8, 1445-1482, doi:10.5194/acp-8-1445-2008, 2008. 
Stohl, A.: Computation, accuracy and applications of trajectories a review and bibliography, Atmos. Environ., 32, 947-966, 1998.

Stohl, A., Eckhardt, S., Forster, C., James, P., Spichtinger, N., and Seibert, P.: A replacement for simple back trajectory calculations in the interpretation of atmospheric trace substance measurements, Atmos. Environ., 36, 4635-4648, 2002.

Swartzendruber, P. C., Jaffe, D. A., Prestbo, E. M., Weiss-Penzias, P., Selin, N. E., Park, R., Jacob, D., Strode, S., and Jaeglé, L.: Observations of reactive gaseous mercury in the free-troposphere at the Mt. Bachelor observatory, J. Geophys. Res., 111, D24301, doi:10.1029/2006JD007415, 2006.

Talbot, R., Mao, H., Feddersen, D., Smith, M., Kim, S. Y., Sive, B., Haase, K., Ambrose, J., Zhou, Y., and Russo, R.: Comparison of Particulate Mercury Measured with Manual and Automated Methods, Atmosphere 2, 1-20, doi:10.3390/atmos2010001, 2011.

USEPA: Toxics Release Inventory Explorer, available at: http: //www.epa.gov/triexplorer/facility.htm (last access: 15 December 2010), 2011.

Valente, R. J., Shea, C., Humes, K. L., and Tanner, R. L.: Atmospheric mercury in the Great Smoky Mountains compared to regional and global levels, Atmos. Environ., 41, 1861-1873, 2007.

Viana, M., Kuhlbusch, T. A. J., Querol, X., Alastuey, A., Harrison, R. M., Hopke, P. K., Winiwarter, W., Vallius, M., Szida, S., Prévôt, A. S. H., Hueglin, C., Bloemen, H., Wåhlin, P., Vecchi, R., Miranda, A. I., Kasper-Giebl, A., Maenhaut, W., and Hitzenberge, R.: Source apportionment of particulate matter in Europe: A review of methods and results, J. Aerosol Sci., 39, 827-849, 2008.

Vijayaraghavan, K., Karamchandani, P., Seigneur, C., Balmori, R., and Chen, S.-Y.: Plume-in-grid modeling of atmospheric mercury, J. Geophys. Res., 113, D24305, doi:10.1029/2008JD010580, 2008.

Wang, H. and Shooter, D.: Water soluble ions of atmospheric aerosols in three New Zealand cities: seasonal changes and sources, Atmos. Environ., 35, 6031-6040, 2001.

Wang, Y. Q., Zhang, X. Y., and Arimoto, R.: The contribution from distant dust sources to the atmospheric particulate matter loadings at XiAn, China during spring, Sci. Total. Environ., 368, 875-883, 2006.
Watson, J. G., Chen, L. W. A., Chow, J. C., Doraiswamy, P., and Lowenthal, D. H.: Source Apportionment: Findings from the U.S. Supersites Program, J. Air Waste Manag. Assoc., 58, 265288, doi:10.3155/1047-3289.58.2.265, 2008.

Weiss-Penzias, P., Gustin, M. S., and Lyman, S. N.: Observations of speciated atmospheric mercury at three sites in Nevada: Evidence for a free tropospheric source of reactive gaseous mercury, J. Geophys. Res., 114, D14302, doi:10.1029/2008JD011607, 2009.

$\mathrm{Xu}, \mathrm{X}$. and Akhtar, U. S.: Identification of potential regional sources of atmospheric total gaseous mercury in Windsor, Ontario, Canada using hybrid receptor modeling, Atmos. Chem. Phys., 10, 7073-7083, doi:10.5194/acp-10-7073-2010, 2010.

Xu, X., Yang, X., Miller, D. R., Helble, J. J., and Carley, R. J.: A regional scale modeling study of atmospheric transport and transformation of mercury. I. Model development and evaluation, Atmos. Environ., 34, 4933-4944, 2000.

Yatavelli, R. L. N., Fahrni, J. K., Kim, M., Crist, K. C., Vickers, C. D., Winter, S. E., and Connell, D. P.: Mercury, PM2.5 and gaseous co-pollutants in the Ohio River Valley region: Preliminary results from the Athens supersite, Atmos. Environ., 40, 6650-6665, 2006.

Yoshimori, M.: Atmospheric Transport Inferred from Seasonal Variations in Cosmogenic Be-7 Concentrations, Proceedings of the 30th International Cosmic Ray Conference, Merida, Mexico, 3-11 July 2007, 224, 2007.

Zhang, L., Vet, R., Wiebe, A., Mihele, C., Sukloff, B., Chan, E., Moran, M. D., and Iqbal, S.: Characterization of the sizesegregated water-soluble inorganic ions at eight Canadian rural sites, Atmos. Chem. Phys., 8, 7133-7151, doi:10.5194/acp-87133-2008, 2008.

Zhang, L., Blanchard, P., Johnson, D., Dastoor, A., Ryzhkov, A., Lin, C.-J., Vijayaraghavan, K., Gay, D., Holsen, T. M., Huang, J., Graydon, J. A., St. Louis, V. L., Castro, M. S., Miller, E. K., Marsik, F., Lu, J., Poissant, L., Pilote, M., and Zhang, K. M.: Assessment of modelled mercury deposition over the Great Lakes region, Environ. Pollut., 161, 272-283, 2012. 